Cochrane Database of Systematic Reviews

\title{
Timing of dornase alfa inhalation for cystic fibrosis (Review)
}

\section{Dentice R, Elkins M}

Dentice R, Elkins M.

Timing of dornase alfa inhalation for cystic fibrosis.

Cochrane Database of Systematic Reviews 2018, Issue 11. Art. No.: CD007923.

DOI: 10.1002/14651858.CD007923.pub5. 
TABLE OF CONTENTS

HEADER 1

ABSTRACT

PLAIN LANGUAGE SUMMARY

SUMMARY OF FINDINGS

BACKGROUND

OBJECTIVES

METHODS

RESULTS

DISCUSSION

AUTHORS' CONCLUSIONS

ACKNOWLEDGEMENTS

REFERENCES

CHARACTERISTICS OF STUDIES

DATA AND ANALYSES

Analysis 1.1. Comparison 1 Pre-ACT versus Post-ACT, Outcome 1 FEV1 (L).

Analysis 1.2. Comparison 1 Pre-ACT versus Post-ACT, Outcome 2 FEV1 (\% pred).

Analysis 1.3. Comparison 1 Pre-ACT versus Post-ACT, Outcome 3 FVC (L).

Analysis 1.4. Comparison 1 Pre-ACT versus Post-ACT, Outcome 4 FVC (\% pred).

Analysis 1.5. Comparison 1 Pre-ACT versus Post-ACT, Outcome 5 FEF25-75 (\% pred).

Analysis 1.6. Comparison 1 Pre-ACT versus Post-ACT, Outcome 6 FEF25 (L).

Analysis 1.7. Comparison 1 Pre-ACT versus Post-ACT, Outcome 7 FEF25 (\% pred).

Analysis 2.1. Comparison 2 Morning versus Evening, Outcome 1 FEV1 (L).

Analysis 2.2. Comparison 2 Morning versus Evening, Outcome 2 FEV1 (\% pred).

Analysis 2.3. Comparison 2 Morning versus Evening, Outcome 3 FVC (L).

Analysis 2.4. Comparison 2 Morning versus Evening, Outcome 4 FVC (\% pred).

Analysis 2.5. Comparison 2 Morning versus Evening, Outcome 5 FEF25 (\% pred).

ADDITIONAL TABLES

APPENDICES

WHAT'S NEW

HISTORY

CONTRIBUTIONS OF AUTHORS

DECLARATIONS OF INTEREST

SOURCES OF SUPPORT

DIFFERENCES BETWEEN PROTOCOL AND REVIEW

INDEX TERMS 
[Intervention Review]

\section{Timing of dornase alfa inhalation for cystic fibrosis}

Ruth Dentice ${ }^{1}$, Mark Elkins²

1Department of Respiratory Medicine, Royal Prince Alfred Hospital, Camperdown, Australia. ${ }^{2}$ Sydney Medical School, University of Sydney, Sydney, Australia

Contact address: Ruth Dentice, Department of Respiratory Medicine, Royal Prince Alfred Hospital, Level 11, E Block, Missenden Road, Camperdown, New South Wales, NSW 2050, Australia. ruth.dentice@health.nsw.gov.au.

Editorial group: Cochrane Cystic Fibrosis and Genetic Disorders Group.

Publication status and date: Edited (no change to conclusions), published in Issue 3, 2019.

Citation: Dentice R, Elkins M. Timing of dornase alfa inhalation for cystic fibrosis. Cochrane Database of Systematic Reviews 2018, Issue 11. Art. No.: CD007923. DOI: 10.1002/14651858.CD007923.pub5.

Copyright @ 2019 The Cochrane Collaboration. Published by John Wiley \& Sons, Ltd.

\section{A B S T R A C T}

\section{Background}

Inhalation of the enzyme dornase alfa reduces sputum viscosity and improves clinical outcomes of people with cystic fibrosis. This is an update of a previously published Cochrane Review.

\section{Objectives}

To determine whether the timing of dornase alfa inhalation (in relation to airway clearance techniques or morning versus evening inhalation) has an impact on objective and subjective measures of clinical efficacy in people with cystic fibrosis.

\section{Search methods}

Relevant randomised and quasi-randomised controlled trials were identified from the Cochrane Cystic Fibrosis Trials Register, Physiotherapy Evidence Database (PEDro), clinical trial registries and international cystic fibrosis conference proceedings.

Date of the most recent search: 06 June 2018.

\section{Selection criteria}

Any trial of dornase alfa in people with cystic fibrosis where timing of inhalation was the randomised element in the trial with either: inhalation before compared to after airway clearance techniques; or morning compared to evening inhalation.

\section{Data collection and analysis}

Both authors independently selected trials, assessed risk of bias and extracted data with disagreements resolved by discussion. Relevant data were extracted and, where possible, meta-analysed.

\section{Main results}

We identified 115 trial reports representing 55 trials, of which five trials (providing data on 122 participants) met our inclusion criteria. All five trials used a cross-over design. Intervention periods ranged from two to eight weeks. Four trials (98 participants) compared dornase alfa inhalation before versus after airway clearance techniques. Inhalation after instead of before airway clearance did not significantly change forced expiratory volume at one second (very-low quality evidence). Similarly, forced vital capacity (low-quality evidence) and quality of life (very-low quality evidence) were not significantly affected; forced expiratory flow at $25 \%$ was significantly worse with dornase alfa inhalation after airway clearance, mean difference -0.17 litres (95\% confidence interval -0.28 to -0.05 ), based on the pooled data from two small trials in children (7 to 19 years) with well-preserved lung function. All other secondary outcomes were statistically non-significant.

In one trial (25 participants), morning versus evening inhalation had no impact on lung function or symptoms (low-quality evidence). 


\section{Authors' conclusions}

The current evidence derived from a small number of participants does not indicate that inhalation of dornase alfa after airway clearance techniques is more or less effective than the traditional recommendation to inhale nebulised dornase alfa 30 minutes prior to airway clearance techniques, for most outcomes. For children with well-preserved lung function, inhalation before airway clearance may be more beneficial for small airway function than inhalation after. However, this result relied on a measure with high variability and trials with variable follow-up. In the absence of strong evidence to indicate that one timing regimen is better than another, the timing of dornase alfa inhalation can be largely based on pragmatic reasons or individual preference with respect to the time of airway clearance and time of day. Further research is warranted.

\section{PLAIN LANGUAGE SUMMARY}

\section{The timing of inhalation of dornase alfa in people with cystic fibrosis}

\section{Review question}

To determine the effect of timing of dornase alfa inhalation on measures of effectiveness in people with cystic fibrosis (in relation to airway clearance techniques or time of day). This is an update of a previously published Cochrane review.

\section{Background}

Inhaling the enzyme dornase alfa reduces the stickiness of sputum and improves clinical outcomes in people with cystic fibrosis. It is not certain whether it is better to inhale dornase alfa before or after clearing the airways with physical techniques. It is also not clear whether it is better to inhale it in the morning or in the evening.

\section{Search date}

The evidence is current to: 06 June 2018.

\section{Study characteristics}

We included five trials with a total of 122 participants. In these trials the length of treatment ranged from two to eight weeks.

\section{Key results}

Four of the trials compared inhaling before to inhaling after the airways had been cleared and found no overall difference in clinical outcomes. However, in children with well-preserved lung function, inhaling of dornase alfa after airway clearance techniques was better for small airways function. However, this did not affect quality of life or other outcomes. In the remaining trial, morning versus evening inhalation had no impact on lung function or symptoms. Therefore, for many people with cystic fibrosis, the timing of dornase alfa inhalation (before or after airway clearance or the time of day) can be based on practical reasons or individual preference.

\section{Quality of the evidence}

Apart from one trial published only in abstract form, the quality of the evidence ranged from low to very low. This was due to issues relating to group allocation, blinding, incomplete reporting of outcome data and the the limited age range of participants. 
SUMMARY OF FINDINGS

Summary of findings for the main comparison. Inhalation of dornase alfa before versus after airway clearance techniques

DNase inhalation before versus after ACTs for cystic fibrosis

Patient or population: adults and children with cystic fibrosis

Settings: outpatients

Intervention: DNase inhalation before ACT

Comparison: DNase inhalation after ACT

\begin{tabular}{|c|c|c|c|c|c|c|}
\hline \multirow[t]{3}{*}{ Outcomes } & \multicolumn{2}{|c|}{$\begin{array}{l}\text { Illustrative comparative } \\
\text { risks }{ }^{\star}(95 \% \mathrm{Cl})\end{array}$} & \multirow{3}{*}{$\begin{array}{l}\text { Relative ef- } \\
\text { fect } \\
(95 \% \mathrm{CI})\end{array}$} & \multirow{3}{*}{$\begin{array}{l}\text { No of partici- } \\
\text { pants } \\
\text { (studies) }\end{array}$} & \multirow{3}{*}{$\begin{array}{l}\text { Quality of the } \\
\text { evidence } \\
\text { (GRADE) }\end{array}$} & \multirow[t]{3}{*}{ Comments } \\
\hline & Assumed risk & $\begin{array}{l}\text { Correspond- } \\
\text { ing risk }\end{array}$ & & & & \\
\hline & $\begin{array}{l}\text { Inhalation } \\
\text { after airway } \\
\text { clearance }\end{array}$ & $\begin{array}{l}\text { Inhalation } \\
\text { before air- } \\
\text { way clear- } \\
\text { ance }\end{array}$ & & & & \\
\hline $\begin{array}{l}\text { FEV }_{\mathbf{1}} \text { (\% predict- } \\
\text { ed) } \\
\text { change from } \\
\text { baseline } \\
\text { Follow-up: up to } \\
4 \text { weeks }\end{array}$ & \multicolumn{2}{|l|}{ See comments. } & $\begin{array}{l}\mathrm{MD} 0.83 \% \\
(95 \% \mathrm{Cl} \\
-2.96 \% \text { to } \\
1.31 \%)\end{array}$ & $\begin{array}{l}102 \\
\text { ( } 4 \text { cross-over } \\
\text { studies) }\end{array}$ & $\begin{array}{l}\oplus \ominus \ominus \ominus \\
\text { very low } 1,2,3\end{array}$ & $\begin{array}{l}\text { Positive MD indicates an advantage for DNase inhalation be- } \\
\text { fore ACT, but difference is not statistically significant. } \\
\text { FEV }_{1}(\mathrm{~L}) \text { also showed no significant difference between groups. } \\
\text { Participants received both ACTs as cross-over design. }\end{array}$ \\
\hline $\begin{array}{l}\text { Measures of QoL } \\
\text { and symptom } \\
\text { scores }\end{array}$ & \multicolumn{2}{|l|}{ See comments. } & NA & 102 & $\begin{array}{l}\oplus \ominus \ominus \ominus \\
\text { very low } 1,2,3\end{array}$ & $\begin{array}{l}4 \text { trials reported a variety of QoL scores (CFQ and QWB) and } \\
\text { symptom scores covering well-being, sputum (volume, viscosi- } \\
\text { ty and ease of clearance), and cough (daytime and nighttime). }\end{array}$ \\
\hline
\end{tabular}




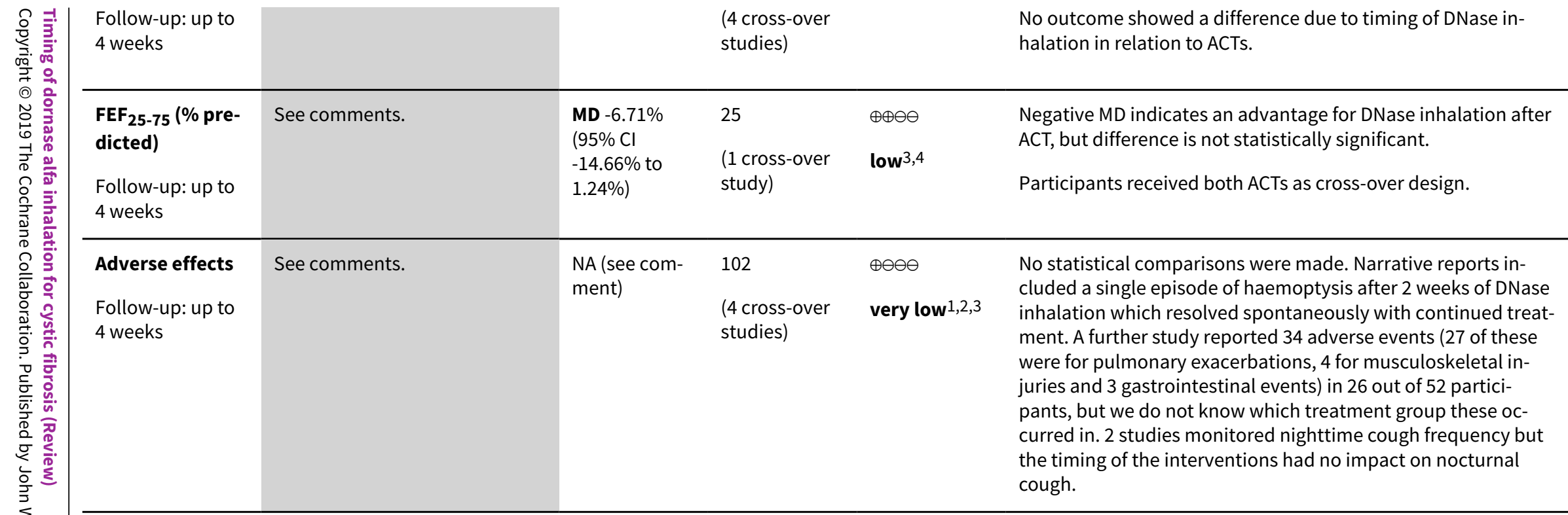

Relative effect and $95 \% \mathrm{Cl}$ presented is adjusted for the cross-over design of the studies.

ACT: airway clearance technique; $\mathbf{C l}$ : confidence interval; $\mathbf{C S S}$ : cough symptom score; $\mathbf{D N a s e : ~ d o r n a s e ~ a l f a ; ~} \mathbf{F E F}_{\mathbf{2 5}-\mathbf{7 5}}$ : mid-forced expiratory volume; $\mathbf{F E V}_{\mathbf{1}}$ : forced expiratory volume in 1 second; MD: mean difference; NA: not applicable; QoL: quality of life; VAS: visual analogue scale.

GRADE Working Group grades of evidence

High quality: further research is very unlikely to change our confidence in the estimate of effect.

Moderate quality: further research is likely to have an important impact on our confidence in the estimate of effect and may change the estimate.

Low quality: further research is very likely to have an important impact on our confidence in the estimate of effect and is likely to change the estimate.

Very low quality: we are very uncertain about the estimate.

1. Downgraded once for high risk of bias due to lack of allocation concealment.

2. Downgraded once for high risk of bias due to lack of blinding.

3. Downgraded once for high risk of bias due to incomplete outcome data.

4. Downgraded once for lack of applicability as studies included only children so results are not applicable to adults.

\section{Summary of findings 2 . Morning versus evening inhalation of dornase alfa}

Morning versus evening inhalation of DNase for cystic fibrosis

Patient or population: adults and children with cystic fibrosis

Settings: outpatients

Intervention: morning DNase inhalation 
Comparison: evening DNase inhalation

\begin{tabular}{|c|c|c|c|c|c|c|}
\hline \multirow[t]{3}{*}{ Outcomes } & \multicolumn{2}{|c|}{$\begin{array}{l}\text { Illustrative comparative } \\
\text { risks }^{\star}(95 \% \mathrm{Cl})\end{array}$} & \multirow{3}{*}{$\begin{array}{l}\text { Relative ef- } \\
\text { fect } \\
(95 \% \mathrm{CI})\end{array}$} & \multirow{3}{*}{$\begin{array}{l}\text { No of partici- } \\
\text { pants } \\
\text { (studies) }\end{array}$} & \multirow{3}{*}{$\begin{array}{l}\text { Quality of the } \\
\text { evidence } \\
\text { (GRADE) }\end{array}$} & \multirow[t]{3}{*}{ Comments } \\
\hline & Assumed risk & $\begin{array}{l}\text { Correspond- } \\
\text { ing risk }\end{array}$ & & & & \\
\hline & $\begin{array}{l}\text { Evening in- } \\
\text { halation }\end{array}$ & $\begin{array}{l}\text { Morning in- } \\
\text { halation }\end{array}$ & & & & \\
\hline $\begin{array}{l}\text { FEV }_{\mathbf{1}} \text { (\% predicted) } \\
\text { change from baseline } \\
\text { Follow-up: up to } 4 \text { weeks }\end{array}$ & \multicolumn{2}{|l|}{ See comments. } & $\begin{array}{l}\text { MD }-1.30 \% \\
(95 \% \mathrm{Cl} \\
-4.18 \% \text { to } \\
1.58 \%)\end{array}$ & $\begin{array}{l}25 \\
(1 \text { cross-over } \\
\text { study) }\end{array}$ & $\begin{array}{l}\oplus \oplus \ominus \ominus \\
\text { low }^{1,2}\end{array}$ & $\begin{array}{l}\text { Negative MD indicates an advantage for evening DNase } \\
\text { inhalation, but difference is not statistically significant. } \\
\mathrm{FEV}_{1}(\mathrm{~L}) \text { also showed no significant difference between } \\
\text { groups. } \\
\text { Participants received both morning and evening DNase } \\
\text { inhalation as cross-over design. }\end{array}$ \\
\hline $\begin{array}{l}\text { FVC (\% predicted) } \\
\text { change from baseline } \\
\text { Follow-up: up to } 4 \text { weeks }\end{array}$ & \multicolumn{2}{|l|}{ See comments. } & $\begin{array}{l}\text { MD }-0.10 \% \\
(95 \% \mathrm{Cl} \\
-5.98 \% \text { to } \\
5.78 \%)\end{array}$ & $\begin{array}{l}25 \\
(1 \text { cross-over } \\
\text { study) }\end{array}$ & $\begin{array}{l}\oplus \oplus \ominus \ominus \\
\text { low }^{1,2}\end{array}$ & $\begin{array}{l}\text { Negative MD indicates an advantage for evening DNase } \\
\text { inhalation, but difference is not statistically significant } \\
\text { FVC (L) also showed no significant difference between } \\
\text { groups. } \\
\text { Participants received both morning and evening DNase } \\
\text { inhalation as cross-over design. }\end{array}$ \\
\hline $\begin{array}{l}\text { Measures of QoL and } \\
\text { symptom scores } \\
\text { Follow-up: up to } 4 \text { weeks }\end{array}$ & \multicolumn{2}{|l|}{ See comments. } & NA & $\begin{array}{l}25 \\
\text { (1 cross-over } \\
\text { study) }\end{array}$ & $\begin{array}{l}\oplus \oplus \ominus \ominus \\
\text { low }^{1,2}\end{array}$ & $\begin{array}{l}\text { A variety of VAS scores reported on cough (day and } \\
\text { night), sputum (volume and viscosity), appetite and } \\
\text { sleep quality; none of which were significantly different } \\
\text { as a result of the time of day the DNase was inhaled. }\end{array}$ \\
\hline $\begin{array}{l}\text { FEF }_{\mathbf{2 5 - 7 5}} \text { (\% predicted) } \\
\text { Follow-up: up to } 4 \text { weeks }\end{array}$ & \multicolumn{2}{|c|}{ Oucome not reported. } & NA & NA & NA & \\
\hline $\begin{array}{l}\text { Adverse effects } \\
\text { Follow-up: up to } 4 \text { weeks }\end{array}$ & \multicolumn{2}{|l|}{ See comments. } & $\begin{array}{l}\text { NA (see com- } \\
\text { ment) }\end{array}$ & $\begin{array}{l}25 \\
\text { (1 cross-over } \\
\text { study) }\end{array}$ & $\begin{array}{l}\oplus \oplus \ominus \ominus \\
\text { low }^{1,2}\end{array}$ & $\begin{array}{l}\text { No statistical comparisons made. Narrative reports indi- } \\
\text { cated that evening DNase inhalation did not adversely } \\
\text { impact overnight oximetry or cough per hour recordings } \\
\text { (but between-group comparisons were not provided for } \\
\text { this outcome). }\end{array}$ \\
\hline
\end{tabular}

Relative effect and $95 \% \mathrm{Cl}$ presented is adjusted for the cross-over design of the studies. 


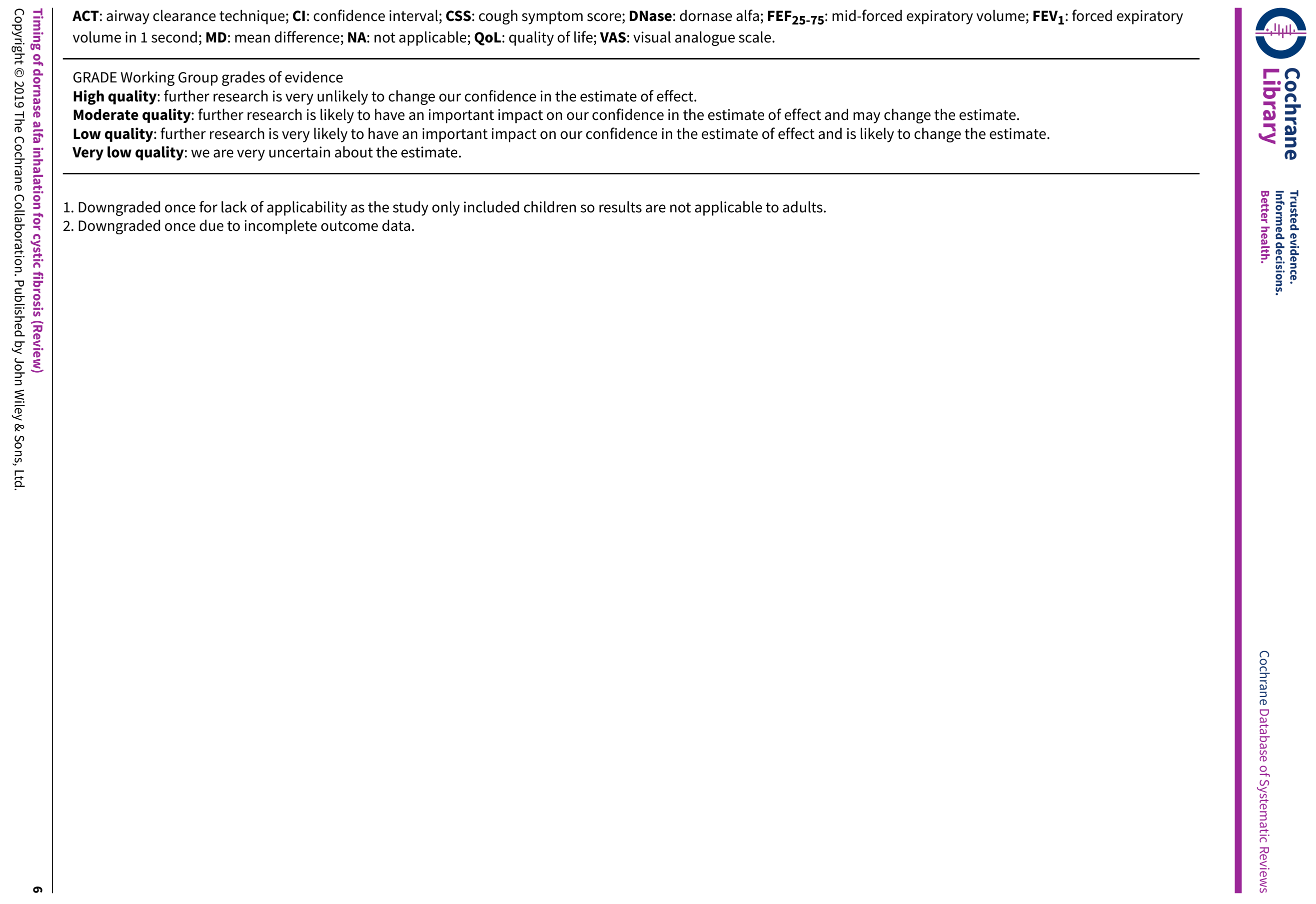




\section{B A C K G R O U N D}

\section{Description of the condition}

Cysic fibrosis (CF) is the most common life-limiting autosomal recessive disorder amongst Caucasians (Cutting 2002). Cystic fibrosis-related pulmonary disease is the major cause of morbidity and mortality (Buzzetti 2009).

\section{Description of the intervention}

The enzyme recombinant human deoxyribonuclease (dornase alfa), has been shown to reduce the viscosity of sputum taken from people with CF by digesting the deoxyribonucleic acid (DNA) released from neutrophils (Lieberman 1968). The proprietary name of dornase alfa is Pulmozyme ${ }^{\circledast}$ (produced by Genentech Inc). Therapy with dornase alfa over a one-, six- or 12-month period is associated with an improvement in lung function in CF (Jones 2010).

A single daily dose of $2.5 \mathrm{mg}$ of dornase alfa is not less effective than higher dosing regimens (Fuchs 1994; Ramsey 1993).

\section{How the intervention might work}

Traditionally, people with CF have been advised to nebulise dornase alfa 30 minutes prior to airway clearance techniques. This recommendation is based on evidence that Pulmozyme ${ }^{\circledast}$ makes CF sputum pourable within 30 minutes (Shak 1990). Alternatively, it is also hypothesised that dornase alfa deposition to peripheral airways may be improved after airway clearance techniques have cleared the larger central airways.

Theoretical arguments can also be put forward to support morning inhalation of dornase alfa. Given that spontaneous mucociliary clearance is faster during waking hours than sleep (Bateman 1978), morning inhalation of dornase alfa may capitalise on faster daytime mucociliary clearance and on the clearance effects of daytime activities such as exercise (Wolff 1977). Some people with CF find evening inhalation more convenient or report that it improves ease of expectoration the following morning. Since mucociliary clearance and coughing are suppressed overnight, evening inhalation of dornase alfa may increase its dwell time in the airways, possibly increasing its clinical efficacy. However, evening inhalation could theoretically induce cough and impair sleep quality.

\section{Why it is important to do this review}

Cystic fibrosis is associated with a high treatment burden in terms of time and money for both people with the disease and for their care providers. Given the high costs specifically associated with dornase alfa therapy, efforts to optimise the timing of inhalation for optimal clinical efficacy are important. This is an update of a previously published Cochrane review (Dentice 2011; Dentice 2013).

\section{OB JECTIVES}

To determine whether the timing of dornase alfa inhalation (in relation to airway clearance techniques or morning versus evening inhalation) has an impact on objective and subjective measures of clinical efficacy in people with CF.

\section{METHODS}

\section{Criteria for considering studies for this review}

Types of studies

Controlled clinical trials (published and unpublished). Trials with either random allocation and quasi-random allocation (e.g. where there is alternate allocation to groups) were included.

\section{Types of participants}

People of all ages and of both sexes with CF diagnosed by genetic testing or evidence on sweat chloride or nasal potential difference, including all degrees of disease severity.

\section{Types of interventions}

Any dornase alfa trial in people with CF where timing of inhalation was the randomised element in the trial protocol:

1. inhalation up to six hours before airway clearance techniques compared to inhalation up to six hours after airway clearance techniques;

2. morning compared to evening inhalation with any definition provided by the author. If not defined, we accepted midnight to midday as morning and midday to midnight as evening.

Dornase alfa treatment given as a minimum of a single dose of at least $2.5 \mathrm{mg}$.

\section{Types of outcome measures}

\section{Primary outcomes}

1. Lung function (absolute change and change in per cent predicted)
a. forced expiratory volume at one second $\left(\mathrm{FEV}_{1}\right)$
b. forced vital capacity (FVC)

2. Measures of quality of life and symptom scores (including cough or subjective ease of clearance)

\section{Secondary outcomes}

1. Measures of sputum clearance, including measures of mucociliary clearance and objective measures of sputum volume

2. Measures of exercise capacity

3. Mortality

4. Other pulmonary parameters
a. forced expiratory flow between $25 \%$ and $75 \%$ of the vital capacity $\left(\mathrm{FEF}_{25-75}\right)$
b. maximal instantaneous forced flow when $25 \%$ of the forced vital capacity remains to be exhaled $\left(\mathrm{FEF}_{25}\right)$
c. total lung capacity (TLC)
d. residual volume (RV)
e. functional residual capacity (FRC) 
5. Frequency of exacerbations of respiratory infection where a clear definition is described demonstrating an increase in symptoms or a decline in pulmonary function

a. admission rates to hospital (defined as either number of inpatient hospital admissions or days as a hospital inpatient)

b. courses of IV antibiotics (whether received in hospital or in the home)

c. outpatient treatments (presentations to hospital, unscheduled visits to the doctor)

6. Adherence to treatment along with other treatments while the protocol for inhalation timing is followed

7. Adverse effects such as bronchospasm, cough and acute decline in pulmonary function

\section{Search methods for identification of studies}

A comprehensive search strategy was formulated in an attempt to identify all relevant trials regardless of language or publication status (published, unpublished, in press, and in progress).

\section{Electronic searches}

The Cochrane Cystic Fibrosis and Genetic Disorders Group's Information Specialist conducted a systematic search of the Group's Cystic Fibrosis Trials Register for relevant trials using the following term: dornase alfa.

The Cystic Fibrosis Trials Register is compiled from electronic searches of the Cochrane Central Register of Controlled Trials (CENTRAL) (updated each new issue of the Cochrane Library), weekly searches of MEDLINE, a search of Embase to 1995 and the prospective handsearching of two journals - Pediatric Pulmonology and the Journal of Cystic Fibrosis. Unpublished work is identified by searching the abstract books of three major cystic fibrosis conferences: the International Cystic Fibrosis Conference; the European Cystic Fibrosis Conference and the North American Cystic Fibrosis Conference. For full details of all searching activities for the register, please see the relevant section of the Cochrane Cystic Fibrosis and Genetic Disorders Group's website.

Date of last search of the Group's Cystic Fibrosis Register: 06 June 2018.

We also searched the Physiotherapy Evidence Database (PEDro) for all years available (Appendix 1; Appendix 2; Appendix 3; Appendix 4).

Date of the most recent search: 17 July 2018.

In addition to the above, we carried out further searches of the following clinical trial registers:

- ClinicalTrials.gov (www.ClinicalTrials.gov);

- World Health Organization (WHO) International Clinical Trials Registry Platform (ICTRP) Search Portal (apps.who.int/ trialsearch/) (Appendix 5).

Date of the most recent search: 17 July 2018.

\section{Searching other resources}

We hand-searched the Australia and New Zealand CF Conference Proceedings (1999 to 2017).
We also contacted Roche in an attempt to identify further relevant trials. Experts in the use of dornase alfa inhalation were also contacted.

\section{Data collection and analysis}

\section{Selection of studies}

Both authors independently selected the trials to be included in the review, with disagreements resolved by discussion.

\section{Data extraction and management}

Each author independently extracted data from included trials using a standardised data extraction form. We resolved any disagreements by discussion. Where data were absent or difficult to interpret in the presented form the authors contacted the trial author in an attempt to gain the information required to evaluate trial quality or facilitate data analysis, or both.

\section{For change-from-baseline data:}

Where the mean difference (MD) and standard error (SE) of the MD were available, we entered these directly into the meta-analysis. If only group means and standard deviations (SD) were available, we planned the following analysis. We planned to calculate the MD by subtraction of one group mean from the other. We planned to impute the SD of the differences from that obtained from raw data in another included trial that used the same measurement scale, and was most similar in terms of the degree of measurement error and the time period between baseline and final value measurement. We then planned to calculate the SEs using the formula: imputed SD / $\sqrt{ } \mathrm{n}$. However, we obtained MD and SE of the MD for all included trials in the current review.

\section{For final-value data:}

Where the between-group MD and SE of the MD were available, we entered these directly into the meta-analysis. Where these were not available, we used the MD and the $P$ value from the paired t-test to calculate the SE around the MD.

We planned to report outcomes at up to one week, between one week and two months, and more than two months. However, the included trials all had intervention arms of two to eight weeks and thus outcomes were reported within a single subdivision. We plan to use the other subdivisions if trials of shorter or longer duration are included in future updates of this review.

\section{Assessment of risk of bias in included studies}

Each author independently determined the risk of bias for each trial following the domain-based evaluation as described in the Cochrane Handbook for Systematic Reviews of Interventions (Higgins 2011). We assessed the following domains as having either a low risk, unclear risk or high risk of bias:
1. randomisation;
2. concealment of allocation;
3. blinding (of participants, personnel and outcome assessors);
4. incomplete outcome data;
5. selective outcome reporting;
6. other sources of bias. 
We resolved any disagreements by discussion. In addition, each author independently rated each trial on the PEDro Scale (Maher 2003), using published and unpublished data from the trial authors. Note that these scores may differ slightly from those on the PEDro database as those are based on the published versions only.

\section{Measures of treatment effect}

For dichotomous data we used the risk ratio (RR) with 95\% confidence intervals $(95 \% \mathrm{Cls})$ as a measure of treatment effect with an intention-to-treat analysis. For continuous data we recorded the difference in mean change from baseline and SD (or SEs) for each group, or the final group means and SDs if change data were unavailable. We calculated a pooled estimate of treatment effect using the MD with $95 \% \mathrm{Cls}$.

\section{Unit of analysis issues}

We incorporated data from cross-over trials into the meta-analyses using the generic inverse variance method, involving expression of data in terms of the paired MDs between treatments and their SE. We calculated these values either from paired individual patient data provided by authors, or by calculation of MDs between interventions and their SE from means, SDs and $P$ values reported in the manuscript (Elbourne 2002). If parallel trials are included in future versions of this review, we intend to combine data from parallel-designed trials with those from cross-over trials in the meta-analyses where appropriate. Otherwise we will consider parallel-designed and cross-over trials separately. If necessary, we will calculate the SEs in parallel-designed trials from the MDs between treatments and their Cls.

\section{Dealing with missing data}

Where data were absent or difficult to interpret in the presented form, the authors contacted the trial authors in an attempt to obtain the data in a form that would facilitate data analysis.

\section{Assessment of heterogeneity}

We estimated the statistical heterogeneity using the $\mathrm{I}^{2}$ value (Higgins 2003). We considered heterogeneity of $0 \%$ to $40 \%$ as low, $30 \%$ to $60 \%$ as moderate, $50 \%$ to $90 \%$ as substantial and $75 \%$ to $100 \%$ as considerable.

\section{Assessment of reporting biases}

We planned to assess publication bias using a funnel plot had we been able to identify 10 trials, bearing in mind that there are other reasons for funnel plot asymmetry, so this should be interpreted with caution. Due to insufficient data we are currently unable to do this, but plan to undertake this analysis if we include sufficient trials in future updates of this review. If we suspected outcome reporting bias, we contacted the trial authors to find out if they measured and analysed an outcome and obtained the data. We contacted experts in the field to ensure unpublished trials were located.

\section{Data synthesis}

We performed meta-analyses using a fixed-effect model. In future versions of the review, if we observe substantial heterogeneity, as defined above, we will use a random-effects model.

\section{Subgroup analysis and investigation of heterogeneity}

We planned a subgroup analysis excluding trials delivering dornase alfa more than 30 minutes either side of physiotherapy in a subgroup analysis, but no eligible trial warranted this action.

\section{Sensitivity analysis}

We performed sensitivity analyses by excluding trials of low quality (less than 5/10 on the PEDro Scale (de Morton 2009; Maher 2003)). We planned sensitivity analysis by excluding cross-over trials, however, our current search did not identify any eligible parallel trials.

\section{Summary of findings and the quality of the evidence (GRADE)}

In a post hoc change, we have presented two summary of findings tables, one for each comparison (Summary of findings for the main comparison, Summary of findings 2). We have included the following outcomes: FEV1, FVC, measures of quality of life and symptoms scores, $\mathrm{FEF}_{25-75}$, and adverse events.

We determined the quality of the evidence using the GRADE approach; and downgraded evidence in the presence of a high risk of bias in at least one study, indirectness of the evidence, unexplained heterogeneity or inconsistency, imprecision of results, high probability of publication bias. We downgraded evidence by one level if we considered the limitation to be serious and by two levels if very serious.

\section{RE S U L T S}

\section{Description of studies}

\section{Results of the search}

The electronic searches identified 115 trial reports which represented 55 trials. Of these, four trials met our inclusion criteria (Bishop 2011; Fitzgerald 2005; van der Giessen 2007a; van der Giessen 2007b). A further trial was identified in international CF conference proceedings in poster format (Anderson 2009). The five included trials provided data for 122 participants. Fifteen reports (representing six trials) were disregarded on title alone and we excluded 45 trials, predominantly because they did not address the timing issue of dornase alfa inhalation (Excluded studies). One of these trials did not precisely match either of the two comparisons specified for this review, i.e. before versus after airway clearance techniques and morning versus evening inhalation (Wilson 2007). However, the comparison it examined (short versus long dwell time) is relevant to the broad topic of this review. Therefore, we intend to add an additional comparison to the next version of this review to allow inclusion of trials comparing long versus short dwell time. This is discussed further in the Discussion section of this review.

\section{Included studies}

We included five trials, which provided data for 122 participants; one trial has not yet been published in full but has been presented as a poster at a conference (Anderson 2009). Four trials investigated the impact of timing in relation to airway clearance physiotherapy (Anderson 2009; Fitzgerald 2005; Bishop 2011; van der Giessen 2007a). One trial investigated the issue of morning versus evening inhalation (van der Giessen 2007b). 


\section{Inhalation before versus after airway clearance techniques}

\section{Trial characteristics}

Four cross-over trials (98 participants) investigated the impact of timing in relation to airway clearance techniques. The duration of intervention blocks were two weeks (Bishop 2011; Fitzgerald 2005), three weeks (van der Giessen 2007a) and eight weeks (Anderson 2009). One trial had a two-week washout between intervention arms (Fitzgerald 2005). The longest trial (four months duration with two eight-week intervention arms) was small in sample size and experienced significant dropouts (three out of eight participants); limited data were provided in conference poster proceedings and additional information was provided by the author (Anderson 2009).

\section{Participants}

Clarification of participant data was requested from the authors of the four trials.

Three trials included children (Anderson 2009; Fitzgerald 2005; van der Giessen 2007a). The participants had mean ages of 10.7 years (Fitzgerald 2005), 11 years (Anderson 2009), and 12 years (van der Giessen 2007a). In these participants, $\mathrm{FEV}_{1}$ was well preserved at $83 \%, 81 \%$ and $88 \%$ predicted respectively. The children had a clinically stable baseline for two to four weeks leading into two trials (Fitzgerald 2005; van der Giessen 2007a) and at time of entry in one trial (Anderson 2009).

One trial included adults only; mean age 27 years, but with a broad age range (19 to 67 years) (Bishop 2011). The adult trial included participants with a broad range of lung function (FEV 1 20\% to $97 \%$ predicted), who were clinically stable for the two weeks leading into the trial.

Participants were on maintenance dornase alfa in two trials (Anderson 2009; van der Giessen 2007a). In the remaining two trials the participants were dornase alfa naive (Bishop 2011; Fitzgerald 2005).

\section{Interventions}

The duration of each timing intervention ranged from two to eight weeks; two trials had an intervention block of two weeks, one of three weeks and one of eight weeks.

One trial provided limited information other than the description 'delivery before airway clearance techniques compared to delivery after airway clearance' (Anderson 2009).

In the three remaining trials, when dornase alfa was delivered first, it was inhaled 30 minutes before airway clearance techniques (Bishop 2011; Fitzgerald 2005; van der Giessen 2007a). Inhalation after airway clearance was immediate in two trials (Bishop 2011; van der Giessen 2007a) and 30 minutes after in one trial (Fitzgerald 2005). All three included a placebo, thus two inhalations were performed for a single session of airway clearance techniques. The clearance technique was stated as positive expiratory pressure (PEP) in the majority, but some also noted active cycle of breathing techniques, Flutter, autogenic drainage, or postural drainage and percussion.

\section{Outcomes measured}

All four trials looked at improvements in lung function $\left(\mathrm{FEV}_{1}\right)$ at the conclusion of the intervention arm. Some reported data for FVC, $\mathrm{FEF}_{25-75}$ and $\mathrm{FEF}_{25}$. A variety of quality of life and symptom scores were reported. All trials reported the incidence of any adverse events. All trials except one reported adherence (Anderson 2009). Data were supplied by the investigators of all trials to supplement the information that was available in their abstract and poster (Anderson 2009; Bishop 2011; Fitzgerald 2005; van der Giessen 2007a).

\section{Morning versus evening inhalation}

\section{Trial characteristics}

One randomised, blinded, cross-over, placebo-controlled trial (providing data for 24 participants) investigated the issue of morning (on waking) versus evening (pre-bedtime) inhalation (van der Giessen 2007b).

\section{Participants}

We requested clarification of participant data from the authors of this trial. It was a trial of children whose mean age was 13 years old (range 6 years to 19 years). Their mean $\mathrm{FEV}_{1}$ was $75 \%$ predicted and they were described as clinically stable in the month prior to the trial. Participants were on maintenance dornase alfa.

\section{Interventions}

Each intervention block in this trial lasted for two weeks; there was no washout period reported.

The clearance technique used in this trial was predominantly PEP mask $(62 \%)$, with autogenic drainage $(17 \%)$, Flutter $(13 \%)$ or a combination in smaller numbers. The clearance technique was performed for 30 minutes post morning inhalation, with a placebo being used so that inhalations were performed twice daily.

\section{Outcomes measured}

This trial reported on lung function $\left(\mathrm{FEV}_{1}, \mathrm{FVC}, \mathrm{FEF}_{25}\right)$, symptom scores (VAS for cough and cough symptom scoring (CSS) day and night, sleep quality, sputum viscosity and amount), adherence and adverse events.

\section{Excluded studies}

Ninety papers representing 45 trials were added to the Excluded studies section, predominantly because they did not address timing of dornase alfa inhalation. Furthermore, nine were not RCTs, two did not study people with CF, and three did not involve dornase alfa. A further trial considered the impact of dornase alfa dwell time in the lung before airway clearance techniques. It compared a short dwell (median of 0.25 hours) to a long dwell (median of 11.1 hours) (Wilson 2007). While participants were randomised to morning or evening inhalation of dornase alfa, the data were not analysed in relation to this. We considered that long or short dwell time is a separate issue. This is discussed further in the Discussion section.

\section{Risk of bias in included studies}

We assessed the risk of bias of each trial using criteria as described in the Cochrane Handbook for Systematic Reviews of Interventions (Higgins 2011). For each trial we assessed the following: randomisation; concealment of allocation; blinding 
(of participants, personnel and outcome assessors); outcome data reporting (incomplete or selective). We also completed the PEDro Scale for the included trials (de Morton 2009; Maher 2003). The PEDro Scale assesses whether allocation was truly random, whether allocation was concealed, whether the groups were comparable at baseline, whether participants, therapists and assessors were blinded, whether follow up exceeded $85 \%$ for any outcome, whether analysis was by intention-to-treat and whether between group comparisons were made and reported with point estimates and measures of variability (for more detail, see PEDro Scale).

Among the trials of dornase alfa inhalation before versus after airway clearance, PEDro scores ranged from three (Anderson 2009) to nine (Fitzgerald 2005; Bishop 2011). The single trial of dornase alfa inhalation in the morning versus the evening also scored nine (van der Giessen 2007b). All these scores are included in the table Characteristics of included studies.

\section{Inhalation before versus after airway clearance techniques}

\section{Allocation}

\section{Generation of sequence}

No trials reported the method of generation of the random sequence. Two trials reported using block randomisation (Bishop 2011; Fitzgerald 2005) and thus have a low risk of bias. However, two trials stated that they were randomised but did not provide methodology (Anderson 2009; van der Giessen 2007a). Thus the overall risk of bias due to the method of generation of the random sequence is unclear.

\section{Concealment of allocation}

Among the trials of dornase alfa inhalation before versus after airway clearance techniques, allocation was concealed in two trials which both used independent distant pharmacies and which we judged to have a low risk of bias (Bishop 2011; Fitzgerald 2005). Allocation concealment was unclear in one trial which we judged to have an unclear risk of bias (van der Giessen 2007a), and was unconcealed in the final trial which we judged to have a high risk of bias (Anderson 2009). We judged the risk of bias due to unconcealed allocation across all trials to be moderate.

\section{Blinding}

Among the trials of dornase alfa inhalation before versus after airway clearance techniques, blinding was adequate in three trials that used a double-dummy placebo (Bishop 2011; Fitzgerald 2005; van der Giessen 2007a). Thus, the risk of bias due to lack of blinding was low in these trials. Blinding was not used in one trial, giving a high risk of bias (Anderson 2009), but the proportion of data contributed by this trial was very small due to its small sample size. The overall risk of bias due to lack of blinding was therefore low.

\section{Incomplete outcome data}

Among the trials of dornase alfa inhalation before versus after airway clearance techniques, the number (\%) of dropouts was low in three trials: 2 (4\%) (Fitzgerald 2005); 0 (0\%) (Bishop 2011); 1 (4\%) (van der Giessen 2007a), giving a low risk of bias. The number (\%) of dropouts was high in one trial: 3 (37\%) (Anderson 2009), giving a high risk of bias. An intention-to-treat analysis was performed in two trials, giving a low risk of bias (Fitzgerald 2005; Bishop 2011). Intention-to-treat analysis was not performed in two trials due to dropouts as a consequence of pulmonary exacerbations, giving a high risk of bias (Anderson 2009; van der Giessen 2007a). The overall risk of bias was moderate.

\section{Selective reporting}

Although we did not review the trial protocols, we contacted the trial authors of the included trials requesting confirmation that the data they provided includes all outcomes measured in the trials. The authors have confirmed this for all trials, therefore giving no risk of bias due to outcome measures being omitted completely (Anderson 2009; Bishop 2011; Fitzgerald 2005; van der Giessen 2007a). However, a small number of outcomes in each trial that did not significantly differ between groups were only reported as 'non-significant' and further data could not be obtained. Therefore, overall the risk of bias due to selective reporting is low.

\section{Other potential sources of bias}

No other potential sources of bias were identified for any of the trials, suggesting a low risk of bias across trials.

\section{Morning versus evening inhalation \\ Allocation}

\section{Generation of sequence}

The included trial did not report the method of sequence generation (van der Giessen 2007b). Thus the risk of bias due to this is unclear.

\section{Allocation concealment}

The method for concealing allocation and hence risk of bias is unclear (van der Giessen 2007b).

\section{Blinding}

The single trial of dornase alfa inhalation in the morning versus the evening blinded participants, therapists and assessors (van der Giessen 2007b). Therefore the risk of bias was low.

\section{Incomplete outcome data}

There was one $(4 \%)$ dropout in this trial and intention-to-treat analysis was used (van der Giessen 2007b). Therefore the risk of bias was low.

\section{Selective reporting}

We have contacted trial authors of the included trial requesting confirmation that the data provided includes all outcome measured in the trial (van der Giessen 2007b). The trial authors confirmed that all of the outcomes measured were reported, therefore there was no risk of bias due to outcome measures being omitted completely. However, some outcomes were only described as non-significant without provision of data. Therefore the overall risk of bias due to selective reporting is low.

\section{Other potential sources of bias}

No other potential sources were identified, suggesting a low risk of bias.

\section{Effects of interventions}

See: Summary of findings for the main comparison Inhalation of dornase alfa before versus after airway clearance techniques; 
Summary of findings 2 Morning versus evening inhalation of dornase alfa

The quality of the evidence has been graded for those outcomes included in the summary of findings tables. For the definitions of these gradings, please refer to the summary of findings tables (Summary of findings for the main comparison; Summary of findings 2).

\section{Inhalation before versus after airway clearance techniques}

There are four trials included for this comparison with a total of 102 participants (Anderson 2009; Bishop 2011; Fitzgerald 2005; van der Giessen 2007a).

\section{Primary outcomes}

1. Lung function (absolute change and change in $\%$ predicted)

a. FEV 1

Four trials provided data that could be included in the metaanalysis regarding the change in $\mathrm{FEV}_{1}$ in litres (Anderson 2009; Bishop 2011; Fitzgerald 2005; van der Giessen 2007a). There was no significant between-group difference overall, MD -0.03 litres (95\% $\mathrm{Cl}-0.08$ to 0.03 ) with the trend favouring inhalation before airway clearance (Analysis 1.1). In per cent predicted, this between-group difference equated to MD $-0.83 \%$ predicted $(95 \% \mathrm{Cl}-2.96$ to 1.31$)$ (Analysis 1.2) (very low-quality evidence).

Fitzgerald performed a post-hoc subgroup analysis of the 17 participants who were colonised with Pseudomonas aeruginosa persistently for the two years preceding the trial (Fitzgerald 2005). In this subgroup, $\mathrm{FEV}_{1}$ improved significantly more when dornase alfa was inhaled after airway clearance techniques $(P=0.034)$.

\section{b. FVC}

Two trials provided data regarding the change in FVC in litres (Fitzgerald 2005; van der Giessen 2007a). There was no significant between-group difference overall, MD 0.01 litres $(95 \% \mathrm{Cl}-0.05$ to 0.08 ) with the trend favouring inhalation after airway clearance (Analysis 1.3). In per cent predicted, this between-group difference equated to MD $1.06 \%$ predicted $(95 \% \mathrm{Cl}-1.29$ to 3.41$)$ (Analysis 1.4) (low-quality evidence).

One further trial reported a non-significant change in FVC; however, data were not provided (Bishop 2011).

\section{Measures of quality of life and symptom scores}

The four trials reported a variety of quality of life and symptom scores. None changed significantly as a result of timing in relation to airway clearance techniques (very low-quality evidence). The quality of life questionnaires included the Cystic Fibrosis Questionnaire (CFQ) (Bishop 2011), the Quality of Wellbeing ("a composite of mobility scale, physical and social activity scales") (Fitzgerald 2005) and a bespoke subjective questionnaire (Anderson 2009). A visual analogue scale (VAS) was frequently used to report symptom scores including: well being (Bishop 2011); cough (Bishop 2011; van der Giessen 2007a); sputum volume (Bishop 2011; van der Giessen 2007a); sputum viscosity (van der Giessen 2007a); and ease of clearance (Bishop 2011). The paper by van der Giessen also reported a cough VAS and cough symptom score for day and night (van der Giessen 2007a). Most trials reported only that the between-group comparison was non-significant.
However, the symptom data from one trial are presented in Table 1 (van der Giessen 2007a).

\section{Secondary outcomes}

1. Measures of sputum clearance, including measures of mucociliary clearance and objective measures of sputum volume

The Middleton trial reported that 24-hour wet sputum weight and the percentage cleared during physiotherapy did not change in response to timing in relation to airway clearance techniques (Bishop 2011). No other trials reported on this outcome.

\section{Measures of exercise capacity}

Two trials reported non-significant changes in $\mathrm{VO}_{2}$ max measured by 20 or 10 metre shuttle tests (Bishop 2011; Fitzgerald 2005).

\section{Mortality}

No trial reported this outcome.

\section{Other pulmonary parameters}

a. $F F_{25-75}$

The impact of timing with airway clearance techniques on $\mathrm{FEF}_{25-75}$ in per cent predicted was reported to be non-significant $(P=0.07)$ in one trial (van der Giessen 2007a) (low-quality evidence).

\section{b. $\mathrm{FEF}_{25}$}

Two trials provided data that could be included in the metaanalysis regarding the change in $\mathrm{FEF}_{25}$ in litres per second (Anderson 2009; van der Giessen 2007a), with a significant betweengroup difference overall, MD -0.17 litres per second $(95 \% \mathrm{Cl}-0.28$ to -0.05) (Analysis 1.6). In per cent predicted, this between-group difference equated to MD $-5.44 \%$ predicted $(95 \% \mathrm{Cl}-9.23$ to -1.66$)$ (Analysis 1.7). The participants in these trials were children aged 7 years to 19 years.

\section{c. TLC}

No trial reported this outcome.

\section{d. RV}

No trial reported this outcome.

\section{e. FRC}

No trial reported this outcome.

\section{Frequency of exacerbations of respiratory infection}

An exacerbation of respiratory symptoms was reported by some authors as a cause of trial withdrawal. In the trial by van der Giessen, one out of 25 developed a pulmonary exacerbation in the first arm of the trial, during which they inhaled dornase alfa before performing airway clearance techniques. The participant was withdrawn and did not provide data for the second half of the trial (van der Giessen 2007a). Two of three dropouts in the Anderson trial were due to exacerbations (one from each group at the end of the first intervention) (Anderson 2009).

\section{a. admission rates to hospital}

We defined this as either number of inpatient hospital admissions or days as a hospital inpatient. The Fitzgerald paper reported this 
data as an adverse event (see below), but the intervention arm at the time of the event was not stated (Fitzgerald 2005).

\section{b. courses of IV antibiotics (whether received in hospital or in the home)}

Fitzgerald reported three of 52 participants required hospitalisation for intravenous antibiotics; two for exacerbations of suppurative lung disease and one with streptococcal septicaemia. The intervention group at the time of the event was not stated (Fitzgerald 2005).

c. outpatient treatments (presentations to hospital, unscheduled visits to the doctor)

No trial reported this outcome.

\section{Adherence to treatment along with other treatments while the protocol for inhalation timing is followed}

The number of returned vials was reported in two trials (Fitzgerald 2005; van der Giessen 2007a). Fitzgerald had two out of 52 withdraw as a result of protocol violations (for failing to take both inhalations) but continued analysis as intention-to-treat (Fitzgerald 2005). The second trial reported a $98 \%$ adherence rate (range $83 \%$ to $100 \%$ ) (van der Giessen 2007a). A further trial recorded adherence for airway clearance techniques and inhalation with a daily diary but the adherence rate was not reported (Bishop 2011).

\section{Adverse effects such as bronchospasm, cough and acute decline in pulmonary function}

Four trials reported on adverse events, but we were not able to meta-analyse the results (very low-quality evidence). The Middleton trial reported one single episode of haemoptysis after two weeks of dornase alfa inhalation that resolved spontaneously despite continued dornase alfa treatment (Bishop 2011). Fitzgerald reported 34 adverse events that occurred among 26 participants ( 27 were due to exacerbations with previously isolated sputum pathogens, three required hospitalisation for intravenous antibiotics, four were due to musculoskeletal injuries during usual sporting activities and three were gastrointestinal in nature); the intervention group at the time of the event was not stated (Fitzgerald 2005). Cough frequency during the night was monitored by two authors as a potential adverse event without a significant impact of the intervention (Anderson 2009; van der Giessen 2007a).

\section{Morning versus evening inhalation}

One cross-over trial investigated the issue of morning (on waking) versus evening (before bedtime) inhalation with two-week intervention periods (van der Giessen 2007b).

\section{Primary outcomes}

1. Lung function (absolute change and change in per cent predicted)

a. FEV $_{1}$

The change in $\mathrm{FEV}_{1}$ in litres was reported in one trial to be nonsignificant (van der Giessen 2007b), MD 0.04 ( $95 \% \mathrm{Cl}-0.04$ to 0.12) (Analysis 2.1). In per cent predicted, this between-group difference equated to MD -1.30 (95\% Cl-4.18 to 1.58) (Analysis 2.2) (low-quality evidence).

\section{b. FVC}

The change in FVC in litres was reported in one trial to be nonsignificant (van der Giessen 2007b), MD 0.07 ( $95 \% \mathrm{Cl}-0.02$ to 0.15 ) (Analysis 2.3). In per cent predicted, this between-group difference equated to MD -0.10 ( $95 \% \mathrm{Cl}-5.98$ to 5.78 ) (Analysis 2.4) (low-quality evidence).

\section{Measures of quality of life and symptom scores}

A variety of VAS scores were also reported in the van der Giessen paper: cough and CSS day and night; sputum viscosity and amount; none of which were significantly different as a result of the time of day the inhalation was performed (van der Giessen 2007b) (lowquality evidence). The symptom data are presented in Table 2.

\section{Secondary outcomes}

1. Measures of sputum clearance, including measures of mucociliary clearance and objective measures of sputum volume

The included trial did not report this outcome.

\section{Measures of exercise capacity}

The included trial did not report this outcome.

\section{Mortality}

The included trial did not report this outcome.

\section{Other pulmonary parameters}

a. $\mathrm{FEF}_{25-75}$

The included trial did not report this outcome.

\section{b. FEF $_{25}$}

The change in $\mathrm{FEF}_{25}$ in per cent predicted was reported to be nonsignificant (van der Giessen 2007b), MD -3.40 (95\% Cl -9.18 to 2.38) (Analysis 2.5).

c. TLC

The included trial did not report this outcome.

d. RV

The included trial did not report this outcome.

\section{e. FRC}

The included trial did not report this outcome.

\section{Frequency of exacerbations of respiratory infection}

The included trial had one withdrawal out of 25 as a result of a respiratory exacerbation, but did apply an intention-to-treat analysis (van der Giessen 2007b).

\section{a. admission rates to hospital}

The included trial did not report this outcome.

\section{b. courses of IV antibiotics (whether received in hospital or in the home)}

The included trial did not report this outcome.

\section{c. outpatient treatments (presentations to hospital, unscheduled visits to the doctor)}

The included trial did not report this outcome. 
6. Adherence to treatment along with other treatments while the protocol for inhalation timing is followed

The number of returned vials was reported by van der Giessen to give a $97 \%$ adherence rate (range $82 \%$ to $100 \%$ ), but no betweengroup comparison was reported (van der Giessen 2007b).

\section{Adverse effects such as bronchospasm, cough and acute decline in pulmonary function}

Bedtime inhalation did not adversely impact overnight oximetry (mean (SD) in the morning group was 96.2 (1.4) and in the evening group was $96.1(1.6), P=0.78)$. Bedtime inhalation did not adversely impact cough per hour recordings (mean (SD) in the morning group was $3.7(8)$ and in the evening group was $3.3(5), P=0.85$ ), but between-group comparison SDs were not provided (van der Giessen 2007b) (low-quality evidence).

\section{Assessment of heterogeneity}

Meta-analysis was possible for several outcomes $\left(\mathrm{FEV}_{1}\right.$ in litres and per cent predicted, FVC in litres and per cent predicted and $\mathrm{FEF}_{25}$ in litres and per cent predicted). For all these meta-analyses, there was low heterogeneity between trials.

\section{DISCUSSION}

\section{Summary of main results}

The searches identified 115 trial reports, of which five trials (providing data on 122 participants) met our inclusion criteria. All five trials used a cross-over design. Intervention periods ranged from two to eight weeks.

Four trials examined inhalation of dornase alfa before versus after airway clearance techniques. Despite theoretical arguments that one timing regimen may be better than another, meta-analysis of all the available data showed that inhalation after instead of before airway clearance did not change $\mathrm{FEV}_{1}$, MD - 0.03 litres ( $95 \%$ $\mathrm{Cl}-0.08$ to 0.03$)$. Similarly, FVC and quality of life were unaffected. Most of the secondary outcomes were also statistically nonsignificant. However, $\mathrm{FEF}_{25}$ was significantly better with dornase alfa inhalation before airway clearance, based on the pooled data from two small trials (Anderson 2009; van der Giessen 2007a). This evidence of a benefit in small airway function was reinforced by a similar result in $\mathrm{FEF}_{25-75}$ (van der Giessen 2007a), although this did not reach statistical significance. However, it is difficult to judge the importance of this finding for several reasons. Unlike the wellestablished prognostic value of $\mathrm{FEV}_{1}$, we are unaware of evidence for the prognostic value of $\mathrm{FEF}_{25}$. Therefore, it is difficult to interpret whether or not the magnitude of the effect on $\mathrm{FEF}_{25}$ is clinically important, although it did not lead to improvements in symptom scores or quality of life. Furthermore, a decrease in flow at low lung volumes is not necessarily specific for small airway disease and interpretation is hazardous if $\mathrm{FEV}_{1}$ or FVC are abnormal or have varied, or if their ratio is abnormal (Pellegrino 2005). Also, $\mathrm{FEF}_{25}$ is a highly variable measure in healthy adults (Pellegrino 2005) and has poor repeatability in children and adolescents with CF (Cooper 1990). This high variability and the lack of significant effects on all other outcomes make it uncertain how relevant the observed benefits in small airway function are to the clinical well being of people with CF, especially into adulthood.
In one trial, morning versus evening inhalation had no impact on lung function or symptoms (van der Giessen 2007b). Bedtime inhalation had previously been considered a relative contraindication given the hypothesised risk of a reduced therapeutic effect with the absence of an opportunity to expectorate. Concerns had also been raised concerning side effects of nocturnal cough and impaired sleep quality. Given the potential to improve the time burden and acceptability of therapy with the possibility of evening inhalation, this may have significant implications for patient compliance with therapy. Given that only one trial has examined this comparison further trials would improve the precision of these estimates.

\section{Overall completeness and applicability of evidence}

The identified trials were of relatively short duration with a timing intervention ranging from two or three weeks, to a maximum of eight weeks in one trial with very small numbers (Anderson 2009). In addition, none of the trials reported which timing regimen was chosen by participants after trial completion, which may reflect the relative acceptability of the timing regimens overall.

The included trials in this review encompassed a diverse CF patient population in age and disease severity as reflected in $\mathrm{FEV}_{1}$, however, only one of the included trials was conducted in adults (Bishop 2011).

Observations about participants with chronic Pseudomonas aeruginosa colonisation on post hoc analysis in the Fitzgerald trial should be interpreted with caution (Fitzgerald 2005).

Two of the trials included only participants who were naive to dornase alfa (Bishop 2011; Fitzgerald 2005). It is well-recognised that some individuals have a marked response when commencing therapy with dornase alfa while others do not (Ramsey 1993). The large response of these participants during the first arm of the trial will increase the variability in both groups. This will reduce the ability of the trial to identify a treatment effect due to the timing of dornase alfa. Furthermore, there are no data to confirm whether participants with a large response to dornase alfa were evenly distributed between the groups in these trials. Therefore, there is the potential for this effect to introduce further bias.

One additional cross-over trial with two-week intervention periods did not meet the type of intervention specified in our protocol (Wilson 2007). Twenty participants were randomised to morning or evening dornase alfa inhalation to create a lung dwell time of long or short duration, since airway clearance techniques were performed in the morning. The data were analysed to assess the effect of long versus short dwell time. Allowing dornase alfa to dwell in the lungs longer (mean 11 hours) before airway clearance improved $\mathrm{FEF}_{25-75}$ and quality of life significantly more than a short dwell time ( 0.2 hours). We believe this differs importantly from trials of pre- versus post-airway clearance techniques, because the long dwell time is more than six hours after the previous session of airway clearance techniques. The dornase alfa would therefore not be influenced by several factors that occur immediately after airway clearance. The first is that the airways - particularly the large central airways - are presumably at their most cleared state. The second is that airway clearance techniques can cause transient bronchoconstriction. Finally, airway clearance techniques can cause a transient increase in mucociliary clearance after the techniques are completed. The combination of these effects may 
affect the pattern of deposition of the dornase alfa and how quickly it is cleared. It is likely that a long dwell time as used in the Wilson trial has a different mechanism of therapeutic effect than the timing regimen we have examined in the trials comparing inhalation of dornase alfa before versus after airway clearance techniques. In vivo trials demonstrate continued enzymatic activity at six hours, and animal studies at 11 hours (Roche 2005). A longer dwell time therefore has the potential to maximise the mucolytic effect. It remains unclear if this is optimal if airway clearance is too distant from drug delivery and the liquefied mucus is not cleared. We plan to include this type of intervention in the next update of this review.

\section{Quality of the evidence}

Apart from one trial published only in abstract form (Anderson 2009), in relation to the risk of bias domains, the quality of the included trials was moderate.

The quality of the evidence as assessed by GRADE ranged from low to very low. Reasons for downgrading the evidence included risks of bias (due to allocation concealment, blinding and incomplete outcome data) and inapplicability due to the limited age range of participants.

\section{Potential biases in the review process}

No potential biases in the review process were identified.

\section{Agreements and disagreements with other studies or reviews}

A current Cochrane Review considers the evidence for dornase alfa for people with CF, but timing of inhalation is not considered (Yang 2018).

\section{AUTHORS' CONCLUSIONS}

\section{Implications for practice}

For children with well preserved lung function, data derived from a small number of participants indicate that inhalation of dornase alfa before airway clearance techniques may be more beneficial for small airway function, but does not affect other outcomes. In the absence of strong evidence to indicate that one timing regimen is better than another, the timing of of dornase alpha inhalation can be largely based on pragmatic reasons or individual preference with respect to the time of airway clearance and time of day.

\section{Implications for research}

The primary outcome examined by this review $\left(\mathrm{FEV}_{1}\right)$ was not affected by the timing of dornase alfa inhalation with respect to airway clearance or time of day. For the other outcomes of this review, there were some significant findings in individual trials, but further evidence is required in well-designed trials of longer duration. To better investigate the effect on small airway function, a more sensitive measure, such as nitrogen washout, might be used.

This review has identified few RCTs that consider the timing of dornase alfa inhalation. Given the expense in both time and money to both patients and care providers, further research is warranted to attempt to clarify an optimal regimen for dornase alfa therapy. Interestingly, in the current trials no follow up information regarding what participants opted to continue when the trial finished was included, this may have provided valuable insights into subjective treatment efficacy.

\section{ACKNOWLEDGEMENTS}

We thank Tracey Remmington and Nikki Jahnke from the Cochrane Cystic Fibrosis and Genetic Disorders Group for their editorial support and guidance. This systematic review has been possible due to the willingness of the authors of the included trials to give generously of their data and time. We thank them for providing unpublished data. We thank Christine Wilson for providing unpublished data and detailed protocol information that will permit the inclusion of this trial under a new timing comparison in future updates of this review. 


\section{R E F E R E N C E S}

\section{References to studies included in this review}

Anderson 2009 \{published and unpublished data\}

Anderson P, Morton J. Evaluation of two different timings of Pulmozyme nebulisation in relation to chest physiotherapy in children with Cystic Fibrosis. Journal of Cystic Fibrosis 2009;8(Suppl 2):S74.

\section{Bishop 2011 \{published and unpublished data\}}

* Bishop JR, Erskine OJ, Middleton PG. Timing of dornase alpha inhalation does not affect the efficacy of the airway clearance regimen in adults with cystic fibrosis: a randomised crossover trial. Journal of Physiotherapy 2011;57(4):223-9.

Middleton PG, Bishop J. Dornase alpha and physiotherapy - which should be first? A randomised, double-blind, placebo-controlled trial in CF adults. Pediatric Pulmonology 2001;32(Suppl 22):310. [MEDLINE: 97028227]

\section{Fitzgerald 2005 \{published and unpublished data\}}

Fitzgerald DA, Hilton J, Jepson B, Smith L. A crossover, randomized, controlled trial of dornase alfa before versus after physiotherapy in cystic fibrosis. Pediatrics 2005;116(4):e549-54.

* Fitzgerald DA, Hilton J, Smith L, Jepson B. Is dornase alfa (Pulmozyme) more effective before or after physiotherapy? A cross-over, randomised, placebo-controlled trial. Pediatric Pulmonology 2001;32(Suppl 22):309-10. [MEDLINE: 95392717]

van der Giessen 2007a \{published and unpublished data\} van der Giessen L. Does the timing of inhaled dornase alfa matter?. Journal of Cystic Fibrosis 2009;8(Suppl 1):S6-9.

van der Giessen LJ, Gosselink R, de Jongste JC, Hop WCJ, Tiddens HAWM. Timing of nebulisation of rhDNase and airway clearance techniques (ACT) in children with Cystic Fibrosis. Journal of Cystic Fibrosis 2005;4(Suppl):S97.

* van der Giessen LJ, de Jongste JC, Gosselink R, Hop WC, Tiddens HA. RhDNase before airway clearance therapy improves airway patency in children with CF. Pediatric Pulmonology 2007;42(7):624-30.

van der Giessen 2007b \{published and unpublished data\} van der Giessen L. Does the timing of inhaled dornase alfa matter?. Journal of Cystic Fibrosis. Journal of Cystic Fibrosis 2009;8 Suppl 1:S6-9.

van der Giessen LJ, Gosselink R, Hop W, Tiddens H. RhDNase before or after going to sleep in children with cystic fibrosis?. Journal of Cystic Fibrosis 2007;6(Suppl 1):S68.

* van der Giessen LJ, Gosselink R, Hop WC, Tiddens HA. Recombinant human DNase nebulisation in children with cystic fibrosis: before bedtime or after waking up?. European Respiratory Journal 2007;30(4):763-8. [MEDLINE: 96279782]

\section{References to studies excluded from this review}

Adde 2004 \{published data only\}

Adde FV, Borges KTL, Hatanaka ACF, Nakaie CMA, Cardieri JMA, Oliveira $\mathrm{RC}$, et al. Hypertonic saline $\mathrm{X}$ recombinant human DNase: a randomised crossover study in 18 cystic fibrosis patients. Journal of Cystic Fibrosis 2004;3(Suppl 1):S66.

Bakker 2011 \{published data only\}

Bakker EM, Volpi S, Salonini E, Mullinger B, Kroneberg P, Hop WCJ, et al. Efficacy of peripheral deposition of inhaled rhDNase in CF patients during a respiratory tract infection. Journal of Cystic Fibrosis 2010;9 (Suppl 1):S62. [Abstract No.: 239]

Bakker EM, Volpi S, Salonini E, van der Wiel-Kooij EC, Sintnicolaas CJ, Hop WC. Online supplement to 'Improved treatment response to dornase alfa in cystic fibrosis patients using controlled inhalation'. [online]. European Respiratory Journal 2011; Vol. 38, issue 6:1328-35.

* Bakker EM, Volpi S, Salonini E, van der Wiel-Kooij EC, Sintnicolaas CJJCM, Hop WCJ, et al. Improved treatment response to dornase alfa in cystic fibrosis patients using controlled inhalation. European Respiratory Journal 2011;38(6):1328-35.

Bakker M, Volpi S, Salonini E, van der Wiel E, Merkus P, Sintnicolaas $C$, et al. Peripheral versus central deposition of inhaled rhdnase in children with cystic fibrosis. Pediatric Pulmonology 2010;45 (Suppl 33):306. [Abstract No.: 244]

van den Beukel-Bakker M, Volpi S, Salonini E, van der WielKooij EC, Sintnicolaas C, Hop WC, et al. Samll airways response to doenase alfa improves using controlled inhalation: a randomized controlled trial in cystic fibrosis patients. Journal of Cytsic Fibrosis 2011;10 (Suppl 1):S19. [Abstract No.: 175]

\section{Ballmann 2002 \{published data only\}}

Ballmann M, von der Hardt $\mathrm{H}$. Hypertonic saline and recombinant human DNase: a randomised cross-over pilot study in patients with cystic fibrosis. Proceedings of 22nd European Cystic Fibrosis Conference; 1998 June 13-19; Berlin, Germany. 1998:80.

* Ballmann M, von der Hardt H. Hyptertonic saline and recombinant human DNase: a randomised cross-over pilot study in patients with cystic fibrosis. Journal of Cystic Fibrosis 2002;1(1):35-7.

\section{Bollert 1999 \{published data only\}}

* Bollert FG, Paton JY, Marshall TG, Calvert J, Greening AP, Innes JA. Recombinant DNase in cystic fibrosis: a protocol for targeted introduction through n-of-1 trials. Scottish Cystic Fibrosis Group. European Respiratory Journal 1999;13(1):107-13.

Bollert FGE, McArthur DA, Greening AP, Innes JA. Targeted introduction of DNase in Scotland. Pediatric Pulmonology 1995;20(Suppl 12):204. 


\section{Dodd 2000 \{published data only\}}

Dodd ME, Moorcroft AJ, Haworth CS, Francis S, Miles J, Clayton $\mathrm{N}$, et al. The effect of rhDNase on exercise performance and gas trapping in adults with cystic fibrosis: a randomised controlled trial. Proceedings of the 13th International Cystic Fibrosis Congress; 2000 June 4-8; Stockholm, Sweden. 2000:147.

\section{Frederiksen 2006 \{published data only\}}

Frederiksen B, Koch C, Hoiby N, Pressler T, Hansen A. Effect of aerosolised rhDnase (Pulmozyme ${ }^{\circledR}$ ) on pulmonary infections in CF: an open randomised study. Pediatric Pulmonology 2000;30(Suppl 20):246. [MEDLINE: 95392717]

* Frederiksen B, Pressler T, Hansen A, Koch C, Hoiby N. Effect of aerosolized rhDNase (Pulmozyme) on pulmonary colonization in patients with cystic fibrosis. Acta Paediatrica 2006;95(9):1070-4. [MEDLINE: 96279782]

\section{Fuchs 1994 \{published data only\}}

Eisenberg J. Clinical development of rhDNase in the United States [Developpement clinique de la rhDNase aux Etats-Unis]. Archives de Pediatrie 1995;2(7):674-8. [MEDLINE: 95392717]

Fuchs HJ, Borowitz D, Christiansen D, Morris E, Nash M, Ramsey B, et al. Aerosolised recombinant human DNase reduces pulmonary exacerbations and improves pulmonary function in patients with cystic fibrosis. Proceedings of 36th Annual Conference on Chest Disease. 1993.

* Fuchs HJ, Borowitz DS, Christiansen DH, Morris EM, Nash ML, Ramsey BW, et al. Effect of aerosolized recombinant human DNase on exacerbations of respiratory symptoms and on pulmonary function in patients with cystic fibrosis. The Pulmozyme Study Group. New England Journal of Medicine 1994;31(10):637-42.

Menzin J, Oster G, Davies L, Drummond MF, Greiner W, Lucioni $C$, et al. A multinational economic evaluation of rhDNase in the treatment of cystic fibrosis. International Journal of Technology Assessment in Health Care 1996;12(1):52-61. [MEDLINE: 97028227]

Oster G, Huse DM, Lacer MJ, Regan MM, Fuchs HJ. Effects of recombinant human DNase therapy on healthcare use and costs in patients with cystic fibrosis. Annals of Pharmacotherapy 1995;29(5):459-64.

Ramsey B, For the Pulmozyme ${ }^{\mathrm{TM}}$ (rhDNase) Study Group. A summary of the results of the phase III multicenter clinical trial: Aerosol administration of recombinant human DNase reduces the risk of respiratory tract infections and improves pulmonary function in patients with cystic fibrosis. Pediatric Pulmonology 1993;16(Suppl 9):152-3.

von der Schulenburg JM, Greiner W, von der Hardt H. Socioeconomic evaluation of the effect of rhDNase on the cost of treating infections of the respiratory tract in patients with cystic fibrosis [Soziookonomische Evaluation des Einflusses von rhDNase auf die Kosten der Behandlung von Infektionen der Atemwege bei Patienten mit zystischer Fibrose]. Medizinische Klinik 1995;90(4):220-4.

\section{Furuya 2001 \{published data only\}}

Furuya ME, Lezana-Fernandez JL, Vargas MH, HernandezSierra JF, Ramirez-Figueroa JL. Efficacy of human recombinant DNase in pediatric patients with cystic fibrosis. Archives of Medical Research 2001;32(1):30-4.

Grassemann 2004 \{published data only\}

Grassemann H, Lax H, Tresler JW, Colin AA. Dornase alpha and exhaled NO in cystic fibrosis. Pediatric Pulmonology 2004;38(5):379-85.

\section{Griese 1997 \{published data only\}}

Griese M, App EM, Derouix A, Burkert A, Schams A. Recombinant human DNase (rhDNase) influences phospholipid composition, surface activity, rheology and consecutively clearance indices of cystic fibrosis sputum. Pulmonary Pharmacology \& Therapeutics 1997;10(1):21-7. [MEDLINE: 98035417]

\section{Hagelberg 2008 \{published data only\}}

Hagelberg M, Dooley MJ, Poole SG, Leung D, Bailey M, Finlayson F, et al. Direct dispensing of dornase alpha improves adherence and lung function in cystic fibrosis. Journal of Cystic Fibrosis 2008;7(Suppl 2):S27. [MEDLINE: 96279782]

\section{Heijerman 1995 \{published data only\}}

Heijerman HG, van Rossem RN, Bakker W. Effect of rhDNase on lung function and quality of life in adult cystic fibrosis patients. Netherlands Journal of Medicine 1995;46(6):293-7.

\section{Hjelte 1997 \{published data only\}}

Hjelte L, Eliasson H, Ljung M, Lagerstrand L. Improved gas exchange in patients with cystic fibrosis when treated with RhDNase. Proceedings of the 21st European Cystic Fibrosis Conference; 1997 June 1-6; Davos, Switzerland. 1997:183.

\section{Hubbard 1992 \{published data only\}}

Hubbard RC, McElvaney NG, Birrer P, Shak S, Robinson WW, Jolley $C$, et al. A preliminary study of aerosolized recombinant human deoxyribonuclease I in the treatment of cystic fibrosis Comment in: N Engl J Med 1992 Aug 20;327(8):571. New England Journal of Medicine 1992;326(12):812-5.

\section{Lahiri 2012 \{published data only\}}

Lahiri T, Herrington H, Diehl S, Landrigan G. The effect of intranasal dornase alfa on chronic sinusitis in patients with cystic fibrosis: a pilot study. Pediatric Pulmonology 2012;47 Suppl 35:354. [Abstract no.: 365; CFGD Register: CO48]

\section{Laube 1996 \{published data only\}}

Laube BL, Auci RM, Shields DE, Christiansen D, Fuchs HJ, Rosenstein BJ. A randomized, placebo-controlled trial of the effect of recombinant human DNase (rhDNase) on the deposition homogeneity and mucociliary clearance of radioaerosol in patients with cystic fibrosis. Pediatric Pulmonology 1993;16(Suppl 9):S13.5.

* Laube BL, Auci RM, Shields DE, Christiansen DH, Lucas MK, Fuchs HJ, Rosenstein BJ. Effect of rhDNase on airflow obstruction and mucociliary clearance in cystic fibrosis. American Journal of Respiratory and Critical Care Medicine 1996;153(2):752-60. 
Laube 2005 \{published data only\}

* Laube BL, Geller DE, Lin TC, Dalby RN, Diener-West M, Zeitlin PL. Positive expiratory pressure changes aerosol distribution in patients with cystic fibrosis. Respiratory Care 2005;50(11):1438-44.

Laube BL, Lin T, Geller D, Dalby R, Zeitlin P. Positive expiratory pressure alters aerosol distribution in CF [abstract]. Pediatric Pulmonology 2000;30(Suppl 20):247.

\section{Mainz 2008 \{published data only\}}

* Mainz J, Mentzel H, Scheider G, Riethmuller J, Schiller I, Ritschel C, et al. Double-blind, placebo-controlled pilot trial on sinonasal inhalation of dornase alfa in CF [abstract]. Pediatric Pulmonology 2008;43(Suppl 31):305. [MEDLINE: 96279782]

Mainz J, Mentzel HJ, Schneider G, Riethmuller J, Schiller I, Ritschel C, et al. Sinu-nasal inhalation of Dornase alfa in CF. Results of a double-blind placebo-controlled pilot trial. Journal of Cystic Fibrosis 2008;7(Suppl 2):S27. [MEDLINE: 96279782]

\section{Mainz 2010 \{published data only\}}

Mainz JG, Schiller I, Koitschev A, Koitschev C, Riethmuller J, Wiedemann B, et al. Sinonasal inhalation of dornase alfa reduces rhinosinusitis symptoms in CF. Results of a DBPC-crossover-study. Journal of Cystic Fibrosis 2010; Vol. 9 Suppl 1:S23. [Abstract No.: 88]

\section{Majaesic 1996 \{published data only\}}

Majaesic CM, Montgomery M, Jones R, King M. Reduction in sputum viscosity using high frequency chest compressions (HFCC) compared to conventional chest physiotherapy (CCP). Pediatric Pulmonology 1996;22(Suppl 13):308.

\section{Malfroot 1999 \{published data only\}}

Dab I, Malfroot A, Baran D, App EM, Coffiner M, Nagy AM. Randomized multicentric double blind study of safety and efficacy of nacystelyn ${ }^{\circledR}$ DPI versus placebo in rhDNase treated cystic fibrosis patients. American Journal of Respiratory and Critical Care Medicine 2000;161(3):A72.

Malfroot A, Dab I, Baran D, App EM, Coffiner M, Nagy AM. Randomised multicentric double blind study of tolerability and efficacy of a DPI Nacystelyn ${ }^{\circledR}$ versus placebo in cystic fibrosis patients treated by rhDNase for at least 3 months. Proceedings of the 13th International Cystic Fibrosis Congress; 2000 June 4-8; Stockholm, Sweden. 2000:146.

* Malfroot A, Dab I, Baran D, App EM, Coffiner M, Nagy AM. Randomized multicentric double blind study of tolerability and efficacy of a DPI Nacystelyn ${ }^{\circledR}$ versus placebo in cystic fibrosis patients treated by rhDnase for at least 3 months. Pediatric Pulmonology 1999;28(Suppl 19):244.

\section{McCoy 1996 \{published data only\}}

McCoy K, Hamilton S, Johnson C. Effects of 12-week administration of dornase alfa in patients with advanced cystic fibrosis lung disease. Pulmozyme Study Group. Chest 1996;110(4):889-95. [MEDLINE: 97028227]

${ }^{\star}$ McCoy K, for the Pulmozyme ${ }^{\circledR}$ severe Lung Disease Study Group. rhDNase is well tolerated and effective in cystic fibrosis patients with severe obstructive lung disease. Proceedings of the 20th European Cystic Fibrosis Conference; 1995 June 18-21; Brussels, Belgium. 1995:L41.

Minasian 2010 \{published data only\}

* Minasian C, Wallis C, Metcalfe C, Bush A. Comparison of inhaled mannitol, daily rhDNase and a combination of both in children with cystic fibrosis: a randomised trial. Thorax 2010;65(1):51-6.

Minasian CC, Wallis C, Metcalfe C, Bush A. A crossover comparative study of inhaled mannitol, alone and in combination with daily rhDNase, in children with cystic fibrosis. Pediatric Pulmonology 2008;43(Suppl 31):301. [MEDLINE: 96279782]

\section{Nasr 2001 \{published data only\}}

Nasr SZ, Kuhns LR, Brown RW, Hurwitz ME, Sanders GM, Strouse PJ. Aerosolized recombinant human DNase in cystic fibrosis patients younger than 5 years of age. Pediatric Pulmonology 1999;28(Suppl 19):278. [MEDLINE: 97028227]

* Nasr SZ, Kuhns LR, Brown RW, Hurwitz ME, Sanders GM, Strouse PJ. Use of computerized tomography and chest $x$-rays in evaluating efficacy of aerosolized recombinant human DNase in cystic fibrosis patients younger than age 5 years: a preliminary study. Pediatric Pulmonology 2001;31(5):377-82.

\section{Quan 2001 \{published data only\}}

Brody A, Molina PL, Klein JS, Campbell JD, Millard SP, Quan J. High-resolution CT is more sensitive to longitudinal decline in lung status in young children with CF than pulmonary function tests. Pediatric Pulmonology 2003;36(Suppl 25):318.

Konstan MW, Wohl ME, McKenzie S, Sy J, Quan JM, Tiddens HA. A randomized, placebo-controlled trial of two years' treatment with dornase alfa (Pulmozyme ${ }^{\circledR}$ ) in cystic fibrosis patients aged 6-10 years with early lung disease. Pediatric Pulmonology 2000;30(Suppl 20):299-300.

* Quan JM, Tiddens HA, Sy JP, McKenzie SG, Montgomery MD, Robinson PJ, et al. A two-year randomized, placebo-controlled trial of dornase alfa in young patients with cystic fibrosis with mild lung function abnormalities. Journal of Pediatrics 2001;139(6):813-20.

Robinson PJ. Dornase alfa in early cystic fibrosis lung disease. Pediatric Pulmonology 2002;34(3):237-41.

Ramsey 1993 \{published data only\}

Ramsey BW, Astley SJ, Aitken ML, Burke W, Colin AA, Dorkin HL, et al. Efficacy and safety of short-term administration of aerosolized recombinant human deoxyribonuclease in patients with cystic fibrosis. American Review of Respiratory Disease 1993;148(1):145-51.

\section{Ranasinha 1993 \{published data only\}}

Ranasinha C, Assoufi B, Shak S, Christiansen D, Fuchs H, Empey D, et al. Efficacy and safety of short-term administration of aerosolised recombinant human DNase I in adults with stable stage cystic fibrosis. Lancet 1993;342(8865):199-202. 
* Ranasinha C, Empey D, Geddes D, Fuchs H, Hodson ME. A phase 2 double-blind placebo-controlled study of the pulmonary function and the safety of aerosolised recombinant human DNase in adults with stable stage cystic fibrosis. Proceedings of the 11th International Cystic Fibrosis Congress; 1992; Dublin, Ireland. 1992:LBS5.

Shah PL, Dewar A, Hodson ME. Scanning electron microscopy of cystic fibrosis sputum. European Respiratory Journal 1995;8(Suppl 19):574S.

Shah PL, Scott SF, Knight RA, Marriott C, Hodson ME. The effects of recombinant human DNase I on sputum DNA content. European Respiratory Journal 1995;8(Suppl 19):574S.

Shah PL, Scott SF, Knight RA, Marriott C, Ranasinha C, Hodson ME. In vivo effects of recombinant human DNase I on sputum in patients with cystic fibrosis. Thorax 1996;51(2):119-25. [MEDLINE: 96246620]

\section{Riethmueller 2006 \{published data only\}}

Riethmueller J, Borth-Bruhns T, Kumpf M, Vonthein R, Wiskirchen J, Stern M, et al. Recombinant human deoxyribonuclease shortens ventilation time in young, mechanically ventilated children. Pediatric Pulmonology 2006;41(1):61-6.

\section{Robinson 2000 \{published data only\}}

Hemming AL, Robinson M, Moriarty C, Bautovich GJ, Bye PTP. Effect of short course of rhDNase on mucociliary clearance in patients with cystic fibrosis. Pediatric Pulmonology 1997;23(Suppl 14):273.

* Robinson M, Hemming AL, Moriarty C, Eberl S, Bye PT. Effect of a short course of rhDNase on cough and mucociliary clearance in patients with cystic fibrosis. Pediatric Pulmonology 2000;30(1):16-24.

\section{Robinson 2003 \{published data only\}}

Robinson T, Goris ML, Bhise P, Sathi A, Zhu JH, Moss RB. Quantitative HRCT air trapping analysis in CF subjects with mild lung disease during a pulmozyme intervention study. Pediatric Pulmonology 2002;34(Suppl 24):298.

Robinson T, Leung AN, Northway WH, Blankenberg FG, Chan F, Bloch DA, et al. Composite CT/PFT score: An outcome measure which markedly improves sensitivity to change in early cystic fibrosis lung disease. Pediatric Pulmonology 2002;34(Suppl 24):298.

* Robinson TE, Leung AN, Northway WH, Blankenberg FG, Chan FP, Bloch DA, et al. Composite spirometric-computed tomography outcome measure in early cystic fibrosis lung disease. American Journal of Respiratory and Critical Care Medicine 2003;168(5):588-93.

\section{Sanders 2015 \{published data only\}}

Sanders DB, Li Z, Brody AS. Chest computed tomography predicts the frequency of pulmonary exacerbations in children with cystic fibrosis. Annals of the American Thoracic Society 2015;12(1):64-9. [CENTRAL: 1111875; CRS: 5500135000001466; PUBMED: 25474182]

\section{Sawicki 2015 \{published data only\}}

Sawicki GS, Chou W, Raimundo K, Trzaskoma B, Konstan MW. Randomized trial of efficacy and safety of dornase alfa delivered by eRapid nebulizer in cystic fibrosis patients. Journal of Cystic Fibrosis 2015;14(6):777-83. [CENTRAL: 1102262; CRS: 5500135000001415; PUBMED: 25921451]

\section{Shah 1994a \{published data only\}}

Shah PL, Kollnberger SD, Scott SF, Knight RA, Marriott C, Hodson ME. Recombinant Human DNase 1 depolymerises extracellular DNA in vivo. Pediatric Pulmonology 1994;18(Suppl 10):210.

\section{Shah 1994b \{published data only\}}

Shah PL, Scott SF, Marriott C, Hodson ME. Sputum rheology in severely ill patients with cystic fibrosis and the in vivo effects of recombinant human DNase1. Proceedings of the 19th European Cystic Fibrosis Conference; 1994 May 29-June 3; Paris, France. 1994:084.

\section{Shah 1995a \{published data only\}}

Hodson M. Multicenter study of rhDNase in cystic fibrosis with severe pulmonary involvement [Etude multicentrique de la rhDNase dans les mucoviscidoses avec atteinte pulmonaire grave]. Archives de Pediatrie 1995;2(7):679-81. [MEDLINE: 95392718]

Shah PL, Bush A, Cannya J, Colin AA, Fuchs HJ, Geddes DM, et al. Recombinant human DNase I in cystic fibrosis patients with severe pulmonary disease: A short-term, double-blind study followed by six months open-label treatment. European Respiratory Journal 1995;8(6):954-8.

Shah PL, Scott SF, Hodson ME. Report on a multicentre study using aerosolised recombinant human DNase 1 in the treatment of cystic fibrosis patients with severe pulmonary disease [abstract]. Pediatric Pulmonology 1993;16(Suppl 9):157-8.

\section{Shah 1995b \{published data only\}}

Shah PL, Scott SF, Fuchs HJ, Geddes DM, Hodson ME. Medium term treatment of stable stage cystic fibrosis with recombinant human DNase I. Thorax 1995;50(4):333-8. [MEDLINE: 96279782]

\section{Shah 1995c \{published data only\}}

Shah PL, Scott SF, Geddes DM, Hodson ME. Two years experience with recombinant human DNase I in the treatment of pulmonary disease in cystic fibrosis. Respiratory Medicine 1995;89(7):499-502. [MEDLINE: 96279782]

\section{Smith 1994 \{published data only\}}

Smith A, Pepe M, Morlin G, Williams-Warren J, Ramsey B. Effect of rhDNase administration on sputum bacterial density. Pediatric Pulmonology 1994;18(Suppl 10):S14.4.

\section{Suri 2001a \{published data only\}}

Grieve R, Thompson S, Normand C, Suri R, Bush A, Wallis C. A cost-effectiveness analysis of rhDNase in children with cystic fibrosis. International Journal of Technology Assessment in Health Care 2003;19(1):71-9.

Suri R, Grieve R, Normand C, Metcalfe C, Thompson S, Wallis C, et al. Effects of hypertonic saline, alternate day and daily 
rhDNase on healthcare use, costs and outcomes in children with cystic fibrosis. Thorax 2001;56(Suppl 3):iii84.

Suri R, Grieve R, Normand C, Metcalfe C, Thompson S, Wallis C, et al. Effects of hypertonic saline, alternate day and daily rhDNase on healthcare use, costs and outcomes in children with cystic fibrosis. Thorax 2002;57(10):841-6.

Suri R, Marshall LJ, Wallis C, Metcalfe C, Bush A, Shute JK. Effects of recombinant human DNase and hypertonic saline on airway inflammation in children with cystic fibrosis. American Journal of Respiratory and Critical Care Medicine 2002;166(3):352-5.

Suri R, Metcalfe C, Lees B, Flather M, Normand C, Thompson S, et al. A cross-over comparative study of hypertonic saline alternate day and daily rhDNase in children with Cystic Fibrosis. Thorax 2000;55:A75.

* Suri R, Metcalfe C, Lees B, Grieve R, Flather M, Normand C, et al. Comparison of hypertonic saline and alternate-day or daily recombinant human deoxyribonuclease in children with cystic fibrosis: a randomised trial. Lancet 2001;358(9290):1316-21.

Suri R, Metcalfe C, Wallis C, Bush A. Assessing the usefulness of outcomes measured in a cystic fibrosis treatment trial. Respiratory Medicine 2007;101(2):254-60. [MEDLINE: 96279782]

Suri R, Metcalfe C, Wallis C, Bush A. Predicting response to rhDNase and hypertonic saline in children with cystic fibrosis. Pediatric Pulmonology 2004;37(4):305-10.

Suri R, Wallis C, Bush A. Invivo use of hypertonic saline in CF. Pediatric Pulmonology 2000;30(Suppl 20):125-6.

Suri R, Wallis C, Bush A, Thompson S, Normand C, Flather M, et al. A comparative study of hypertonic saline, daily and alternate-day rhDNase in children with cystic fibrosis. Health Technology Assessment 2002;6(34):iii, 1-60.

Suri R, Wallis C, Metcalfe C, Thompson S, Bush A, Shute J. Effects of rhDNase and hypertonic saline on airway inflammation in children with cystic fibrosis. Pediatric Pulmonology 2001;32(Suppl 22):281.

\section{ten Berge 1999 \{published data only\}}

ten Berge M, van der Wiel E, Tiddens HAWM, Merkus PJFM, Hop WCJ, de Jongste JC. Clinical parameters of mucociliary clearance in infants with CF. Netherlands Journal of Medicine 1999;54(Suppl):S3-4.

\section{ten Berge 2003 \{published data only\}}

ten Berg M, van der Wiel E, Tiddens HAWM, Merkus PJFM, Hop WCJ, de Jongste JC. DNase in stable cystic fibrosis infants: a pilot study. Journal of Cystic Fibrosis 2003;2(4):183-8.

\section{Ungewitter 2000 \{published data only\}}

* Ungewitter A, Bertele-Harms RM, Harms HK. RhDNase, lung function and exercise in cystic fibrosis - a double-blind, placebo-controlled, cross-over study. Proceedings of the 13th International Cystic Fibrosis Congress; 2000 June 4-8; Stockholm, Sweden. 2000:147.
Ungewitter A, Bertele-Harms RM, Harms HK. RhDNase, lung function and exercise in cystic fibrosis - a double-blind, placebo-controlled, cross-over study [abstract]. Pediatric Pulmonology 2000;30(Suppl 20):306.

Weck 1999 \{published data only\}

Weck MB, Retsch-Bogart GZ, Scott CS. Efficacy of DNase in individual children using the $\mathrm{N}$-of-1 study design [abstract]. Pediatric Pulmonology 1999;28(Suppl 19):285.

\section{Wilmott 1996 \{published data only\}}

Wilmott R, The DNase Multicenter Study Group, Genetech staff. A phase II, double blind, multicenter study of the safety and efficacy of aerosolized recombinant human DNase I (rhDNase) in hospitalized patients with CF experiencing acute pulmonary exacerbations. Pediatric Pulmonology 1993;16(Suppl 9):154.

* Wilmott RW, Amin RS, Colin AA, DeVault A, Dozor AJ, Eigen H, et al. Aerosolized recombinant human DNase in hospitalized cystic fibrosis patients with acute pulmonary exacerbations. American Journal of Respiratory and Critical Care Medicine 1996;153(6 Pt 1):1914-7. [MEDLINE: 96279782]

\section{Wilson 2007 \{published data only\}}

Wilson CJ, Robbins LJ, Murphy JM, Chang AB. Is a longer time interval between recombinant human deoxyribonuclease (dornase alfa) and chest physiotherapy better? A multicenter, randomized crossover trial. Pediatric Pulmonology 2007;42(12):1110-6. [MEDLINE: 96279782]

\section{Additional references}

\section{Bateman 1978}

Bateman JR, Pavia D, Clark SW. The retention of lung secretions during the night in normal subjects. Clinical Science and Molecular Medicine. Supplement 1978;55(6):523-7.

\section{Buzzetti 2009}

Buzzetti R, Salvatore D, Baldo E, Forneris MP, Lucidi V, Manunza $D$, et al. An overview of international literature from cystic fibrosis registries: 1 . Mortality and survival studies in cystic fibrosis. Journal of Cystic Fibrosis 2009;8(4):229-37.

\section{Cooper 1990}

Cooper PJ, Robertson CF, Hudson IL, Phelan PD. Variability of pulmonary function tests in cystic fibrosis. Pediatric Pulmonology 1990;8(1):16-22.

\section{Cutting 2002}

Cutting GR. Cystic fibrosis. In: Rimon DL, Connor JM, Pyeritz RE, Korf BR editor(s). Principles and Practice of Medical Genetics. 4th Edition. London: Harcourt, 2002:1561-606.

\section{de Morton 2009}

de Morton NA. The PEDro scale is a valid measure of the methodological quality of clinical trials: a demographic study. Australian Journal of Physiotherapy 2009;55(2):129-33. 


\section{Elbourne 2002}

Elbourne DR, Altman DG, Higgins JPT, Curtin F, Worthington HV, Vail A. Meta-analyses involving cross-over trials: methodological issues. International Journal of Epidemiology 2002;31(1):140-9.

\section{Higgins 2003}

Higgins JP, Thompson SG, Deeks JJ, Altman DG. Measuring inconsistency in meta-analyses. BMJ 2003;327(7414):557-60.

\section{Higgins 2011}

Higgins JPT, Altman DG (editors). Chapter 8: Assessing risk of bias in included studies. In: Higgins JPT, Green S (editors). Cochrane Handbook for Systematic Reviews of Interventions Version 5.1.0 [updated March 2011]. The Cochrane Collaboration, 2011. Available from www.cochranehandbook.org.

\section{Jones 2010}

Jones AP, Wallis CE. Dornase alfa for cystic fibrosis. Cochrane Database of Systematic Reviews 2010, Issue 3. [DOI:

10.1002/14651858.CD001127.pub2]

\section{Lieberman 1968}

Lieberman J. Dornase aerosol effect on sputum viscosity in cases of cystic fibrosis. JAMA 1968;205(5):312-3.

\section{Maher 2003}

Maher CG, Sherrington C, Herbert RD, Moseley AM, Elkins M. Reliability of the PEDro Scale for Rating Quality of Randomized Controlled Trials. Physical Therapy 2003;83(8):713-21.

\section{Pellegrino 2005}

Pellegrino R, Viegi G, Brusasco V, Crapo RO, Burgos F, Casaburi R, et al. Interpretative strategies for lung function tests. European Respiratory Journal 2005;26(5):948-68.

\section{CHARACTERISTICS OF STUDIES}

Characteristics of included studies [ordered by study ID]

\section{Roche 2005}

TGA Approved Product Information. Inhaltion Solution (dornase alfa). eMIMS last amendment 2005.

\section{Shak 1990}

Shak S, Capon DJ, Hellmiss R, Marsters SA. Recombinant human DNase I reduces the viscosity of cystic fibrosis sputum. Proceedings of the National Academy of Sciences USA 1990;87(23):9188-92.

\section{Wolff 1977}

Wolff RK, Dolovich MB, Obminski G, Newhouse MT. Effects of exercise and eucapnic hyperventilation on bronchial clearance in man. Journal of Applied Physiology: Respiratory, Environmental and Exercise Physiology 1977;43(1):46-50.

\section{Yang 2018}

Yang C, Montgomery M. Dornase alfa for cystic fibrosis. Cochrane Database of Systematic Reviews 2018, Issue 9. [DOI: 10.1002/14651858.CD001127.pub4]

\section{References to other published versions of this review Dentice 2011}

Dentice R, Elkins M. Timing of dornase alfa inhalation for cystic fibrosis. Cochrane Database of Systematic Reviews 2011, Issue 5. [DOI: 10.1002/14651858.CD007923.pub2]

\section{Dentice 2013}

Dentice R, Elkins M. Timing of dornase alfa inhalation for cystic fibrosis. Cochrane Database of Systematic Reviews 2013, Issue 6. [DOI: 10.1002/14651858.CD007923.pub3]

* Indicates the major publication for the study

Anderson 2009

Methods Randomised, cross-over trial with 2-month interventions.

Measurements were taken at 0, 2, 4 months.

Generation of allocation schedule and concealment of treatment allocation were unclear. ITT analysis was not used.

\begin{tabular}{ll} 
Participants & 8 stable children randomised (mean 11 years, range 8 - 14 years) mean FEV $181 \%$ (range $63 \%$ \\
& Dornase alfa maintenance via eFlow rapid. \\
& There were 3 withdrawals due to exacerbations, time of withdrawal not stated. \\
\hline Interventions & Delivery before airway clearance techniques compared to delivery after airway clearance. \\
& Times in relation to ACT (PEP or AD) unclear. \\
& No placebo or washout. \\
& Maintenance DNase.
\end{tabular}

Outcomes $\quad \mathrm{FEV}_{1}, \mathrm{QOL}$ (Bespoke subjective questionnaire), $\mathrm{FEF}_{25}$.

Notes

Further data obtained from author. 
PEDro 3/10 (Eligibility criteria: yes; random allocation: yes; concealed allocation: no; baseline comparability: yes; blind participants: no; blind therapists: no; blind assessors: no (because not clearly stated); adequate follow-up: no; ITT analysis: no; between-group comparisons: yes; point estimates and variability: no).

\section{Risk of bias}

\begin{tabular}{|c|c|c|}
\hline Bias & Authors' judgement & Support for judgement \\
\hline $\begin{array}{l}\text { Random sequence genera- } \\
\text { tion (selection bias) }\end{array}$ & Unclear risk & $\begin{array}{l}\text { Randomised for } 18 \text { participants who were identified as potential participants, } \\
8 \text { were subsequently enrolled. The method of randomisation was not de- } \\
\text { scribed. }\end{array}$ \\
\hline $\begin{array}{l}\text { Allocation concealment } \\
\text { (selection bias) }\end{array}$ & High risk & $\begin{array}{l}\text { Information from the author suggests the assessor was aware of the allocation } \\
\text { sequence. }\end{array}$ \\
\hline $\begin{array}{l}\text { Blinding (performance } \\
\text { bias and detection bias) } \\
\text { All outcomes }\end{array}$ & High risk & No placebo. Unclear if the assessor blinded. \\
\hline $\begin{array}{l}\text { Incomplete outcome data } \\
\text { (attrition bias) } \\
\text { All outcomes }\end{array}$ & High risk & Not ITT. Unclear from which group the 3 dropouts occurred. \\
\hline $\begin{array}{l}\text { Selective reporting (re- } \\
\text { porting bias) }\end{array}$ & Low risk & $\begin{array}{l}\text { QOL was reported as non-significant in the publication but data were not pro- } \\
\text { vided by authors. }\end{array}$ \\
\hline
\end{tabular}

Bishop 2011

Rethods
Measurements were taken at: -14; 0;14; and 28 days.
Generation of allocation schedule and concealment of treatment allocation were clear.
ITT analysis was used.

\begin{tabular}{ll}
\hline Participants & 17 stable (monitored 2 weeks previously) adults randomised; mean (SD) age 27 years (range 19 years - \\
67 years), mean (SD) $\mathrm{FEV}_{1} 63(23) \%$ predicted (range $\left.20 \%-97 \%\right)$.
\end{tabular}

Interventions

Delivery 30 minutes before airway clearance techniques compared to delivery immediately after airway clearance.

$\mathrm{ACT}=\mathrm{PEP}$ or $\mathrm{PD} /$ percussion.

Dornase alfa naive.

Outcomes $\quad \mathrm{FEV}_{1}, \mathrm{FVC}, \mathrm{QOL}$ (CFQ, VAS for well-being, cough, sputum volume, ease of clearance).

$24 \mathrm{hr}$ wet sputum weight, $\mathrm{VO}_{2} \max (10$ or 20 minute shuttle), adherence (diary), adverse events.

Notes $\quad$ Additional data from authors, manuscript pending publication (Bishop 2011).

PEDro 9/10 (Eligibility criteria: yes; random allocation: yes; concealed allocation: yes; baseline comparability: yes; blind participants: yes; blind therapists: yes; blind assessors: yes; adequate follow-up: yes; ITT analysis: yes; between-group comparisons: yes; point estimates and variability: no).

\section{Risk of bias}

Bias Authors' judgement Support for judgement


Bishop 2011 (Continued)

Random sequence genera- Low risk Block randomisation by an independent was used. tion (selection bias)

Allocation concealment $\quad$ Low risk Independent distant pharmacy.
(selection bias)

(selection bias)

Blinding (performance Low risk

bias and detection bias)

All outcomes

Incomplete outcome data Low risk Raw data available.
(attrition bias)
All outcomes

\begin{tabular}{ll}
\hline $\begin{array}{l}\text { Selective reporting (re- } \\
\text { porting bias) }\end{array}$ & Low risk \\
& $\begin{array}{l}\text { QOL, } 24 \text { hr wet sputum weight, } \mathrm{VO}_{2} \text { max, adherence and adverse events were } \\
\text { reported as non-significant in the publication but data were not provided by } \\
\text { authors. }\end{array}$ \\
\hline
\end{tabular}

\section{Fitzgerald 2005}

Rethods
Rashout.
Measurements were taken at 0, 2, 4 and 6 weeks.
Generation of allocation schedule and concealment of treatment allocation were clear.
ITT analysis was used.

\begin{tabular}{ll}
\hline Participants & 52 stable children randomised; mean (SD) age 10.7 (3.2) years; mean (SD) FEV $183(18) \%$ predicted. \\
& There were 2 withdrawals due to protocol violations (1 nebulisation instead of 2$)$ in the second arm \\
& while inhaling dornase alfa after airway clearance.
\end{tabular}

Interventions
Delivery 30 minutes before airway clearance techniques compared to delivery 30 minutes after airway
clearance.
ACT = 'physiotherapy' or PEP mask.
DNase naive.

\begin{tabular}{ll}
\hline Outcomes & $\mathrm{FEV}_{1}, \mathrm{FVC}, \mathrm{QOL}$ (composite QWB). \\
& $\begin{array}{l}\mathrm{VO}_{2} \mathrm{max} \text { (Shuttle), } \mathrm{FEF}_{25-75} \text {, adherence (vials returned), adverse events (34 in } 26 \text { participants including } \\
\text { diverse symptoms - intervention group unclear). }\end{array}$ \\
\hline Notes & Subgroup analysis FEV for those with Pseudomonas aeruginosa in the preceding 2 years ( $\mathrm{n}=17$ ) \\
& $\begin{array}{l}\text { PEDro 9/10 (Eligibility criteria: yes; random allocation: yes; concealed allocation: yes; baseline compa- } \\
\text { rability: no; blind participants: yes; Blind therapists: yes; blind assessors: yes; adequate follow-up: yes; } \\
\text { ITT analysis: yes; between-group comparisons: yes; point estimates and variability: yes). }\end{array}$ \\
\hline
\end{tabular}

\section{Risk of bias}

\begin{tabular}{lll}
\hline Bias & Authors' judgement & Support for judgement \\
\hline $\begin{array}{l}\text { Random sequence genera- } \\
\text { tion (selection bias) }\end{array}$ & Low risk & Block randomisation by an independent investigator was used. \\
\hline $\begin{array}{l}\text { Allocation concealment } \\
\text { (selection bias) }\end{array}$ & Low risk & Independent distant pharmacy. \\
\hline
\end{tabular}




\section{Fitzgerald 2005 (Continued)}

Blinding (performance bias and detection bias)

All outcomes
Low risk Placebo used; participants, therapists and assessors blinded.

\begin{tabular}{lll}
\hline $\begin{array}{l}\text { Incomplete outcome data } \\
\text { (attrition bias) } \\
\text { All outcomes }\end{array}$ & Low risk & 2 participants did not take both medications in the second arm. \\
\hline $\begin{array}{l}\text { Selective reporting (re- } \\
\text { porting bias) }\end{array}$ & Low risk & $\begin{array}{l}\mathrm{QOL}, \mathrm{VO}_{2} \text { max, } \mathrm{FEF}_{25-75} \text { and adverse events and were reported as non-signifi- } \\
\text { cant in the publication but data were not provided by authors. }\end{array}$
\end{tabular}

\section{van der Giessen 2007a}

\begin{tabular}{ll}
\hline Methods & Randomised, blinded, cross-over placebo-controlled trial with 3-week interventions, no washout. \\
& Measurements were taken at $0,14,21,35$ and 42 days. \\
Generation of allocation schedule and concealment of treatment allocation were unclear. \\
ITT analysis was not used.
\end{tabular}

\begin{tabular}{ll}
\hline Participants & 25 stable (no IV treatment 1 month previously) children randomised: mean age 12 years (range 7 years \\
& -19 years), mean FEV $\mathrm{F}_{1} 88 \%$ predicted. One child dropped out while inhaling dornase alfa before airway \\
clearance.
\end{tabular}

Interventions
Delivery 30 minutes before airway clearance techniques compared to delivery immediately after airway
clearance.
ACT = PEP mask in $75 \%$, Flutter in $13 \%$, ACBT in $4 \%$, AD in $4 \%$ and combination $4 \%$.
Maintenance dornase alfa.

Outcomes

$\mathrm{FEV}_{1}$, FVC, symptom scores (VAS for cough and CSS day \& night, sputum viscosity and amount).

$\mathrm{FEF}_{25-75}, \mathrm{FEF}_{25}$, Rint, adherence (vials), adverse events.

Notes

PEDro 8/10 (eligibility criteria: yes; random allocation: yes; concealed allocation: no; baseline comparability: yes; blind participants: yes; blind therapists: yes; blind assessors: yes; Adequate follow-up: yes; ITT analysis: no; between-group comparisons: yes; point estimates and variability: yes).

\section{Risk of bias}

\begin{tabular}{lll}
\hline Bias & Authors' judgement & Support for judgement \\
\hline $\begin{array}{l}\text { Random sequence genera- } \\
\text { tion (selection bias) }\end{array}$ & Unclear risk & Stated as randomised but no method was described. \\
\hline $\begin{array}{l}\text { Allocation concealment } \\
\text { (selection bias) }\end{array}$ & Unclear risk & Method unclear. \\
\hline $\begin{array}{l}\text { Blinding (performance } \\
\text { bias and detection bias) }\end{array}$ & Low risk & Placebo used; participants, therapists and assessors blinded. \\
$\begin{array}{l}\text { All outcomes } \\
\begin{array}{l}\text { Incomplete outcome data } \\
\text { (attrition bias) } \\
\text { All outcomes }\end{array}\end{array}$ & High risk & Not analysed as ITT, one drop out due to exacerbation. \\
\hline $\begin{array}{l}\text { Selective reporting (re- } \\
\text { porting bias) }\end{array}$ & Low risk & $\begin{array}{l}\text { Adherence data were only provided for the whole trial cohort and not by trial } \\
\text { arm. }\end{array}$ \\
\hline
\end{tabular}




$\begin{array}{ll}\text { Methods } & \text { Randomised, blinded, cross-over placebo-controlled trial with 2-week interventions, no washout. } \\ & \text { Measurements were taken at } 0,14,21 \text { and } 28 \text { days. } \\ & \text { Generation of allocation schedule was clear but concealment of treatment allocation was unclear. } \\ \text { ITT analysis was used. }\end{array}$

\begin{tabular}{ll}
\hline Participants & 25 stable (no IV treatment 1 month previously) children randomised: mean age 13 years (range 6 years - \\
& 19 years); mean $\mathrm{FEV}_{1} 75 \%$ predicted. One child dropped out while inhaling dornase alfa in the evening.
\end{tabular}

\begin{tabular}{ll}
\hline Interventions & $\begin{array}{l}\text { Morning (on waking) compared to evening (before bedtime). ACT performed for } 30 \text { minutes post morn- } \\
\text { ing inhalation. } \\
\text { ACT not described. } \\
\text { Maintenance dornase alfa. }\end{array}$ \\
\hline Outcomes & $\mathrm{FEV}_{1}, \mathrm{FVC}$, symptom scores (VAS for cough and CSS day \& night, sleep quality, sputum viscosity and \\
amount). \\
$\mathrm{FEF}_{25}$, Rint, adherence (vials), adverse events (overnight oximetry and cough per hour recordings). \\
PEDro 9/10 (Eligibility criteria: yes; random allocation: yes; concealed allocation: no; baseline compa- \\
rability: yes; blind participants: yes; blind therapists: yes; blind assessors: yes; adequate follow-up: yes; \\
ITT analysis: yes; between-group comparisons: yes; point estimates and variability: yes).
\end{tabular}

\section{Risk of bias}

\begin{tabular}{|c|c|c|}
\hline Bias & Authors' judgement & Support for judgement \\
\hline $\begin{array}{l}\text { Random sequence genera- } \\
\text { tion (selection bias) }\end{array}$ & Unclear risk & Stated as randomised but no method was described. \\
\hline $\begin{array}{l}\text { Allocation concealment } \\
\text { (selection bias) }\end{array}$ & Unclear risk & Method unclear. \\
\hline $\begin{array}{l}\text { Blinding (performance } \\
\text { bias and detection bias) } \\
\text { All outcomes }\end{array}$ & Low risk & Placebo used; participants, therapists and assessors blinded. \\
\hline $\begin{array}{l}\text { Incomplete outcome data } \\
\text { (attrition bias) } \\
\text { All outcomes }\end{array}$ & Low risk & 1 drop out due to exacerbation, ITT applied. \\
\hline $\begin{array}{l}\text { Selective reporting (re- } \\
\text { porting bias) }\end{array}$ & Low risk & $\begin{array}{l}\text { Adherence data were only provided for the whole trial cohort and not by trial } \\
\text { arm. }\end{array}$ \\
\hline
\end{tabular}

ACT: airway clearance technique

$A D$ : autogenic drainage

CFQ: cystic fibrosis questionnaire

CSS: cough symptom score

SD: standard deviation

$\mathrm{FEF}_{25-75}$ : mid-expiratory flow

$\mathrm{FEV}_{1}$ : forced expiratory volume at one second

FVC: forced vital capacity

ITT: intention-to-treat

IV: intravenous

$\mathrm{FEF}_{25}$ : forced expiratory flow at $25 \%$ of FVC

PD: postural drainage 
PEP: positive expiratory pressure

QOL: quality of life

QWB: quality of well-being scale

Rint: resistance measured by the interrupter technique

VAS: visual analogue scales

$\mathrm{VO}_{2}$ max: measure of the peak volume of oxygen $\left(\mathrm{VO}_{2}\right)$ you can consume and use in a minute

\section{Characteristics of excluded studies [ordered by study ID]}

\begin{tabular}{|c|c|}
\hline Study & Reason for exclusion \\
\hline Adde 2004 & Not timing of dornase alfa. \\
\hline Bakker 2011 & Not timing of dornase alfa. \\
\hline Ballmann 2002 & Not timing of dornase alfa. \\
\hline Bollert 1999 & Not an RCT, not dornase alfa, not timing of dornase alfa. \\
\hline Dodd 2000 & Not timing of dornase alfa. \\
\hline Frederiksen 2006 & Not timing of dornase alfa. \\
\hline Fuchs 1994 & Timing of dornase alfa not addressed by the study. \\
\hline Furuya 2001 & Timing of dornase alfa not addressed by the study. \\
\hline Grassemann 2004 & Timing of dornase alfa not addressed by the study. \\
\hline Griese 1997 & Timing of dornase alfa not addressed by the study. \\
\hline Hagelberg 2008 & Timing of dornase alfa not addressed by the study. \\
\hline Heijerman 1995 & Timing of dornase alfa not addressed by the study. \\
\hline Hjelte 1997 & Timing of dornase alfa not addressed by the study. \\
\hline Hubbard 1992 & Timing of dornase alfa not addressed by the study. \\
\hline Lahiri 2012 & Timing of dornase alfa not addressed by the study. \\
\hline Laube 1996 & Timing of dornase alfa not addressed by the study. \\
\hline Laube 2005 & Timing of dornase alfa not addressed by the study. \\
\hline Mainz 2008 & Timing of dornase alfa not addressed by the study. \\
\hline Mainz 2010 & Timing of dornase alfa not addressed by the study. \\
\hline Majaesic 1996 & Timing of dornase alfa not addressed by the study. \\
\hline Malfroot 1999 & Dornase alfa not assessed in the study. \\
\hline McCoy 1996 & Timing of dornase alfa not addressed by the study. \\
\hline Minasian 2010 & Timing of dornase alfa not addressed by the study. \\
\hline
\end{tabular}




\begin{tabular}{|c|c|}
\hline Study & Reason for exclusion \\
\hline Nasr 2001 & Timing of dornase alfa not addressed by the study. \\
\hline Quan 2001 & Timing of dornase alfa not addressed by the study. \\
\hline Ramsey 1993 & Timing of dornase alfa not addressed by the study. \\
\hline Ranasinha 1993 & Timing of dornase alfa not addressed by the study. \\
\hline Riethmueller 2006 & Not CF participants, timing of dornase alfa not addressed in the study. \\
\hline Robinson 2000 & Timing of dornase alfa not addressed by the study. \\
\hline Robinson 2003 & Timing of dornase alfa not addressed by the study. \\
\hline Sanders 2015 & Not an RCT \\
\hline Sawicki 2015 & Timing of dornase alfa not addressed by the study \\
\hline Shah 1994a & Timing of dornase alfa not addressed by the study. \\
\hline Shah 1994b & Timing of dornase alfa not addressed by the study. \\
\hline Shah 1995a & Not an RCT, timing of dornase alfa not addressed by the study. \\
\hline Shah 1995b & Timing of dornase alfa not addressed by the study. \\
\hline Shah $1995 \mathrm{c}$ & Timing of dornase alfa not addressed by the study. \\
\hline Smith 1994 & Timing of dornase alfa not addressed by the study. \\
\hline Suri 2001a & Timing of dornase alfa not addressed by the study. \\
\hline ten Berge 1999 & Timing of dornase alfa not addressed by the study. \\
\hline ten Berge 2003 & Timing of dornase alfa not addressed by the study. \\
\hline Ungewitter 2000 & Timing of dornase alfa not addressed by the study. \\
\hline Weck 1999 & Not an RCT, timing of dornase alfa not addressed in the study. \\
\hline Wilmott 1996 & Timing of dornase alfa not addressed by the study. \\
\hline \multirow[t]{2}{*}{ Wilson 2007} & $\begin{array}{l}\text { Does not fit the timing interventions specified in this version of the protocol. Likely inclusion as a } \\
\text { new timing intervention in future updates. }\end{array}$ \\
\hline & $\begin{array}{l}\text { PEDro 6/10 (Eligibility criteria: yes; random allocation: yes; concealed allocation: yes; baseline } \\
\text { comparability: no; blind participants: no; blind therapists: no; blind assessors: yes; adequate fol- } \\
\text { low-up: yes; ITT analysis: no; between-group comparisons: yes; point estimates and variability: } \\
\text { yes). }\end{array}$ \\
\hline
\end{tabular}

CF: cystic fibrosis

$\mathrm{RCT}$ : randomised controlled trial 


\section{DATA AND ANALYSES}

\section{Comparison 1. Pre-ACT versus Post-ACT}

\begin{tabular}{|c|c|c|c|c|}
\hline Outcome or subgroup title & $\begin{array}{l}\text { No. of } \\
\text { studies }\end{array}$ & $\begin{array}{l}\text { No. of } \\
\text { partici- } \\
\text { pants }\end{array}$ & Statistical method & Effect size \\
\hline $1 \mathrm{FEV}_{1}(\mathrm{~L})$ & 4 & & $\begin{array}{l}\text { Mean Difference (Fixed, 95\% } \\
\mathrm{Cl} \text { ) }\end{array}$ & Subtotals only \\
\hline 1.1 Over 1 week and up to 2 months & 4 & & $\begin{array}{l}\text { Mean Difference (Fixed, 95\% } \\
\mathrm{Cl} \text { ) }\end{array}$ & $-0.03[-0.08,0.03]$ \\
\hline $2 \mathrm{FEV}_{1}(\%$ pred $)$ & 4 & & $\begin{array}{l}\text { Mean Difference (Fixed, 95\% } \\
\mathrm{Cl} \text { ) }\end{array}$ & Subtotals only \\
\hline 2.1 Over 1 week and up to 2 months & 4 & & $\begin{array}{l}\text { Mean Difference (Fixed, 95\% } \\
\mathrm{Cl} \text { ) }\end{array}$ & $-0.83[-2.96,1.31]$ \\
\hline 3 FVC (L) & 2 & & $\begin{array}{l}\text { Mean Difference (Fixed, 95\% } \\
\mathrm{Cl} \text { ) }\end{array}$ & Subtotals only \\
\hline 3.1 Over 1 week and up to 2 months & 2 & & $\begin{array}{l}\text { Mean Difference (Fixed, 95\% } \\
\mathrm{Cl} \text { ) }\end{array}$ & $0.01[-0.05,0.08]$ \\
\hline 4 FVC (\% pred) & 2 & & $\begin{array}{l}\text { Mean Difference (Fixed, 95\% } \\
\mathrm{Cl} \text { ) }\end{array}$ & Subtotals only \\
\hline 4.1 Over 1 week and up to 2 months & 2 & & $\begin{array}{l}\text { Mean Difference (Fixed, 95\% } \\
\mathrm{Cl} \text { ) }\end{array}$ & $1.06[-1.29,3.41]$ \\
\hline $5 \mathrm{FEF}_{25-75}(\%$ pred $)$ & 1 & & $\begin{array}{l}\text { Mean Difference (Fixed, 95\% } \\
\mathrm{Cl} \text { ) }\end{array}$ & Totals not selected \\
\hline 5.1 Over 1 week and up to 2 months & 1 & & $\begin{array}{l}\text { Mean Difference (Fixed, 95\% } \\
\mathrm{Cl} \text { ) }\end{array}$ & $0.0[0.0,0.0]$ \\
\hline $6 \mathrm{FEF}_{25}(\mathrm{~L})$ & 2 & & $\begin{array}{l}\text { Mean Difference (Fixed, 95\% } \\
\mathrm{Cl} \text { ) }\end{array}$ & Subtotals only \\
\hline 6.1 Over 1 week and up to 2 months & 2 & & $\begin{array}{l}\text { Mean Difference (Fixed, 95\% } \\
\mathrm{Cl} \text { ) }\end{array}$ & $-0.17[-0.28,-0.05]$ \\
\hline $7 \mathrm{FEF}_{25}$ (\% pred) & 2 & & $\begin{array}{l}\text { Mean Difference (Fixed, 95\% } \\
\mathrm{Cl} \text { ) }\end{array}$ & Subtotals only \\
\hline 7.1 Over 1 week and up to 2 months & 2 & & $\begin{array}{l}\text { Mean Difference (Fixed, 95\% } \\
\mathrm{Cl} \text { ) }\end{array}$ & $-5.44[-9.23,-1.66]$ \\
\hline
\end{tabular}


Analysis 1.1. Comparison 1 Pre-ACT versus Post-ACT, Outcome 1 FEV $_{1}$ (L).

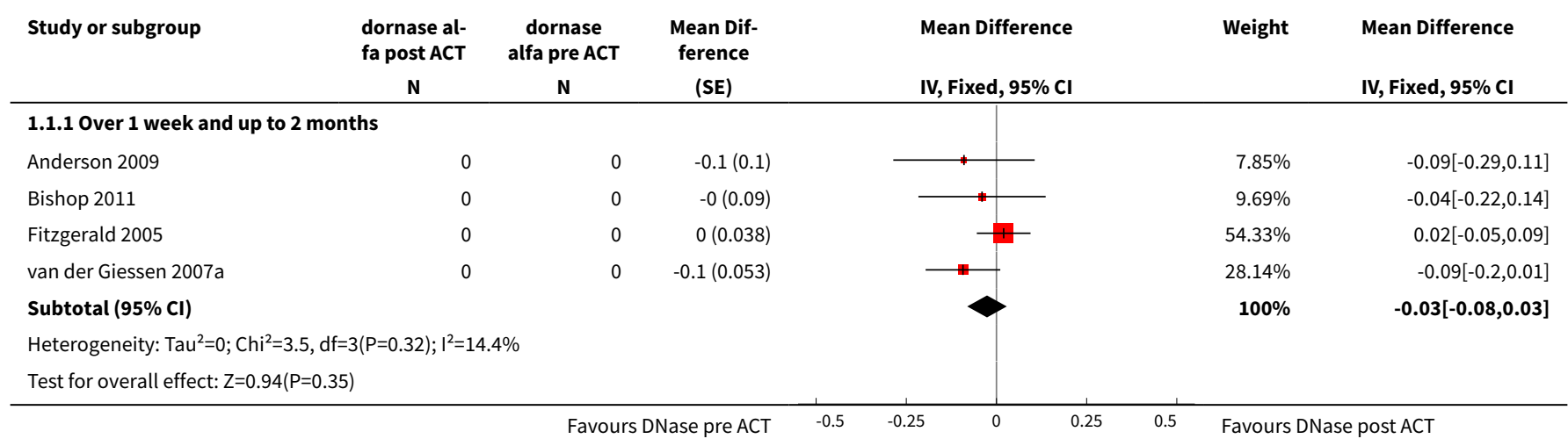

Analysis 1.2. Comparison 1 Pre-ACT versus Post-ACT, Outcome 2 FEV $_{1}$ (\% pred).

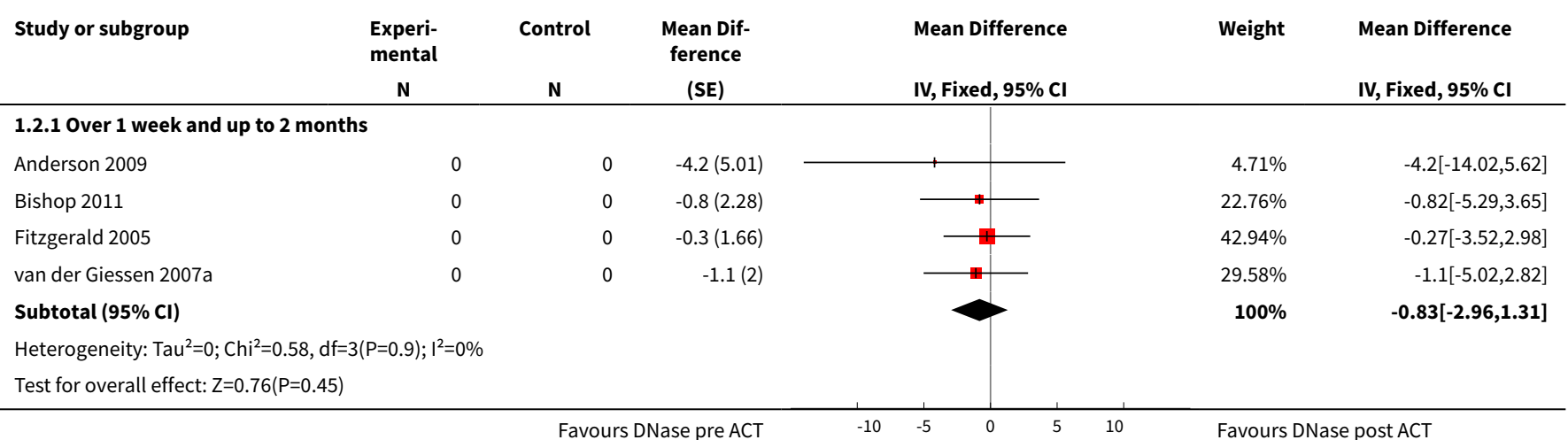

Analysis 1.3. Comparison 1 Pre-ACT versus Post-ACT, Outcome 3 FVC (L).

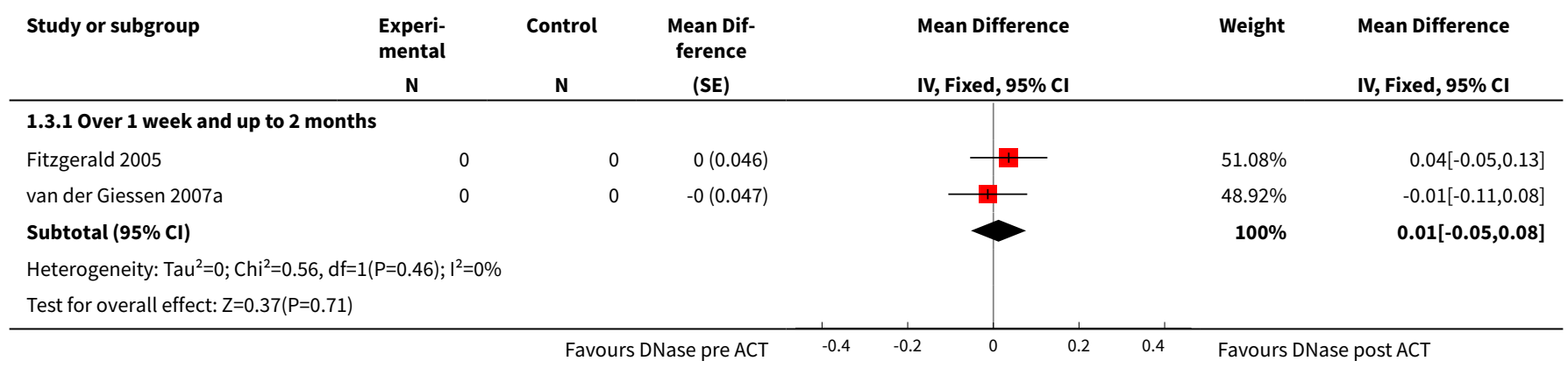


Analysis 1.4. Comparison 1 Pre-ACT versus Post-ACT, Outcome 4 FVC (\% pred).

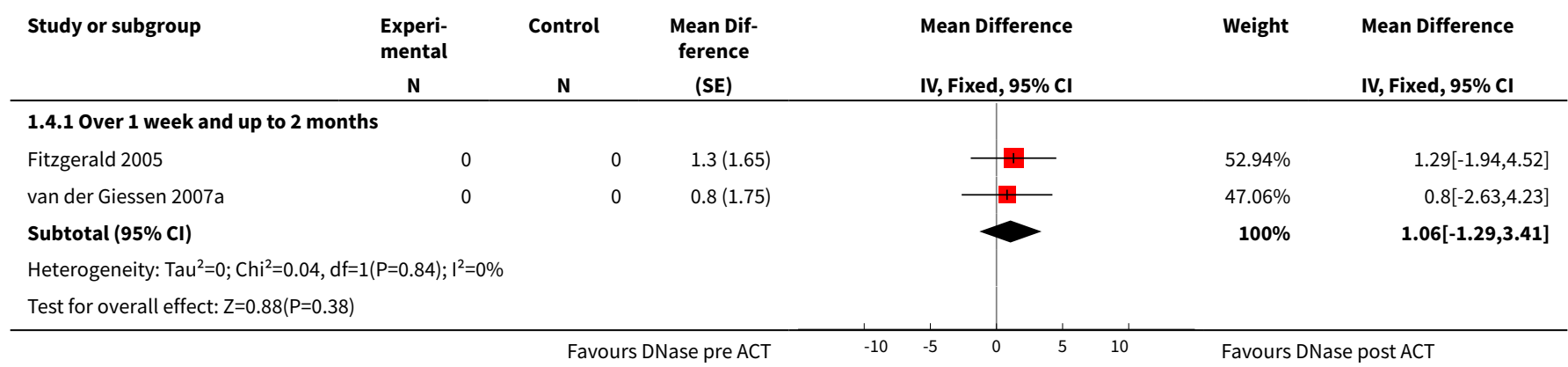

Analysis 1.5. Comparison 1 Pre-ACT versus Post-ACT, Outcome $5 \mathrm{FEF}_{25-75}(\%$ pred).

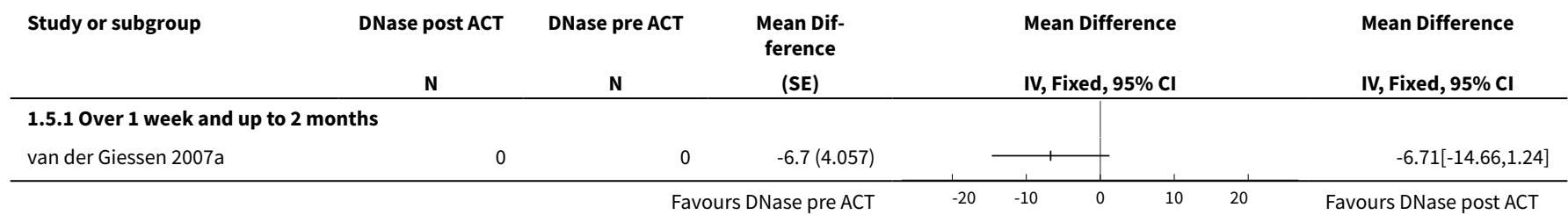

Analysis 1.6. Comparison 1 Pre-ACT versus Post-ACT, Outcome $6 \mathrm{FEF}_{25}$ (L).

\begin{tabular}{|c|c|c|c|c|c|c|}
\hline Study or subgroup & $\begin{array}{c}\text { dornase } \\
\text { alpha } \\
\text { post ACT } \\
N \\
N\end{array}$ & $\begin{array}{c}\text { dornase al- } \\
\text { pha pre ACT } \\
\text { N }\end{array}$ & $\begin{array}{c}\begin{array}{c}\text { Mean Dif- } \\
\text { ference }\end{array} \\
\text { (SE) }\end{array}$ & Mean Difference & Weight & $\begin{array}{l}\text { Mean Difference } \\
\text { IV, Fixed, } 95 \% \mathrm{CI}\end{array}$ \\
\hline \multicolumn{7}{|c|}{ 1.6.1 Over 1 week and up to 2 months } \\
\hline Anderson 2009 & 0 & 0 & $-0(0.14)$ & $\longrightarrow$ & $16.66 \%$ & $-0.05[-0.32,0.22]$ \\
\hline van der Giessen 2007a & 0 & 0 & $-0.2(0.063)$ & + & $83.34 \%$ & $-0.19[-0.31,-0.07]$ \\
\hline Subtotal $(95 \% \mathrm{Cl})$ & & & & & $100 \%$ & $-0.17[-0.28,-0.05]$ \\
\hline \multicolumn{7}{|c|}{ Heterogeneity: Tau $^{2}=0 ; \mathrm{Chi}^{2}=0.84, \mathrm{df}=1(\mathrm{P}=0.36) ; \mathrm{I}^{2}=0 \%$} \\
\hline \multicolumn{7}{|c|}{ Test for overall effect: $Z=2.92(P=0)$} \\
\hline & & Favours & e pre $A C T$ & 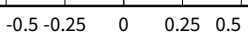 & Favours & post ACT \\
\hline
\end{tabular}

Analysis 1.7. Comparison 1 Pre-ACT versus Post-ACT, Outcome $7 \mathrm{FEF}_{25}$ (\% pred).

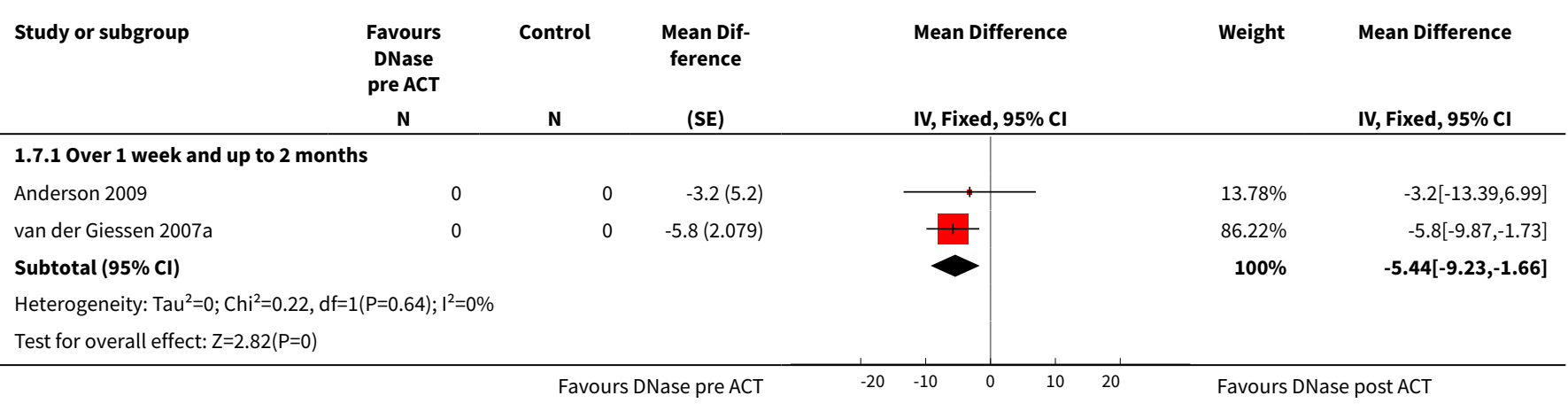


Comparison 2. Morning versus Evening

\begin{tabular}{|c|c|c|c|c|}
\hline Outcome or subgroup title & $\begin{array}{l}\text { No. of } \\
\text { studies }\end{array}$ & $\begin{array}{l}\text { No. of } \\
\text { partici- } \\
\text { pants }\end{array}$ & Statistical method & Effect size \\
\hline $1 \mathrm{FEV}_{1}(\mathrm{~L})$ & 1 & & Mean Difference (Fixed, 95\% Cl) & Totals not selected \\
\hline 1.1 Over 1 week and up to 2 months & 1 & & Mean Difference (Fixed, 95\% CI) & $0.0[0.0,0.0]$ \\
\hline $2 \mathrm{FEV}_{1}(\%$ pred $)$ & 1 & & Mean Difference (Fixed, 95\% CI) & Totals not selected \\
\hline 2.1 Over 1 week and up to 2 months & 1 & & Mean Difference (Fixed, 95\% Cl) & $0.0[0.0,0.0]$ \\
\hline 3 FVC (L) & 1 & & Mean Difference (Fixed, 95\% Cl) & Totals not selected \\
\hline 3.1 Over 1 week and up to 2 months & 1 & & Mean Difference (Fixed, 95\% Cl) & $0.0[0.0,0.0]$ \\
\hline 4 FVC (\% pred) & 1 & & Mean Difference (Fixed, 95\% Cl) & Totals not selected \\
\hline 4.1 Over 1 week and up to 2 months & 1 & & Mean Difference (Fixed, 95\% Cl) & $0.0[0.0,0.0]$ \\
\hline $5 \mathrm{FEF}_{25}$ (\% pred) & 1 & & Mean Difference (Fixed, 95\% Cl) & Totals not selected \\
\hline 5.1 Over 1 week and up to 2 months & 1 & & Mean Difference (Fixed, 95\% CI) & $0.0[0.0,0.0]$ \\
\hline
\end{tabular}

Analysis 2.1. Comparison 2 Morning versus Evening, Outcome $1 \mathrm{FEV}_{1}$ (L).

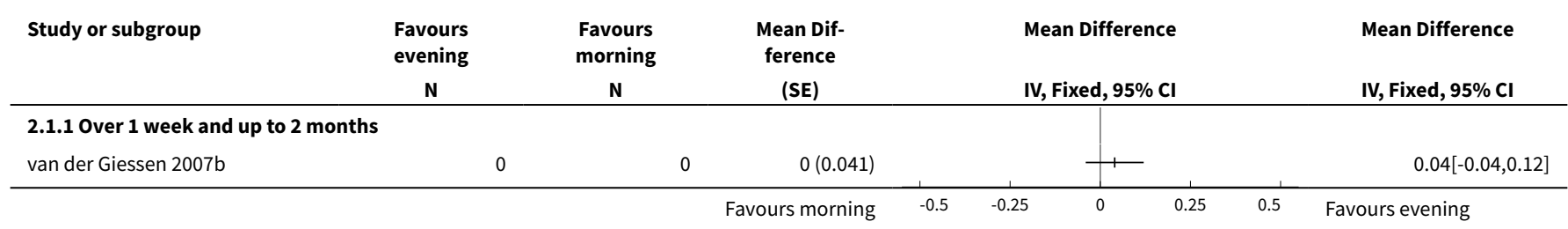

Analysis 2.2. Comparison 2 Morning versus Evening, Outcome 2 FEV $_{1}$ (\% pred).

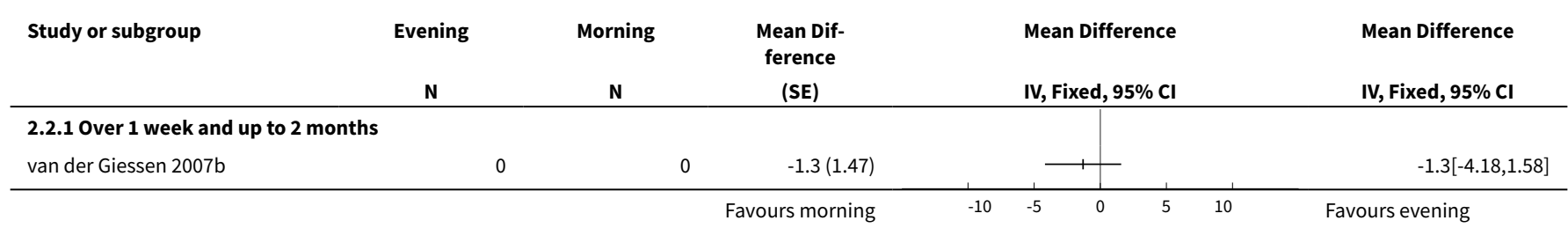


Analysis 2.3. Comparison 2 Morning versus Evening, Outcome 3 FVC (L).

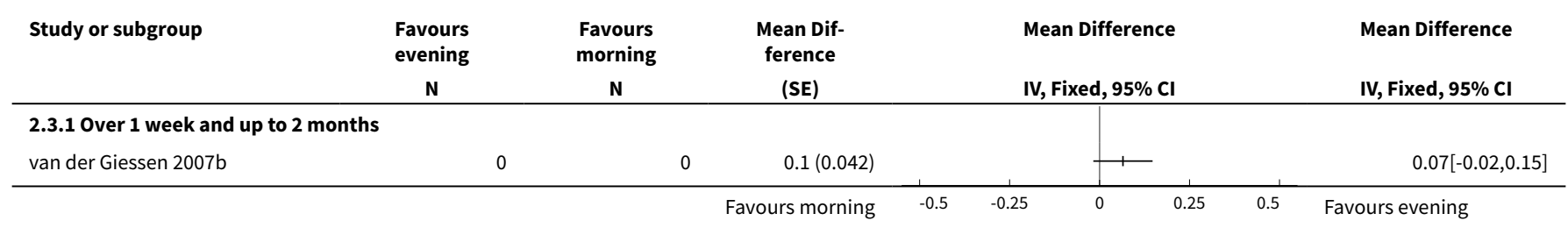

Analysis 2.4. Comparison 2 Morning versus Evening, Outcome 4 FVC (\% pred).

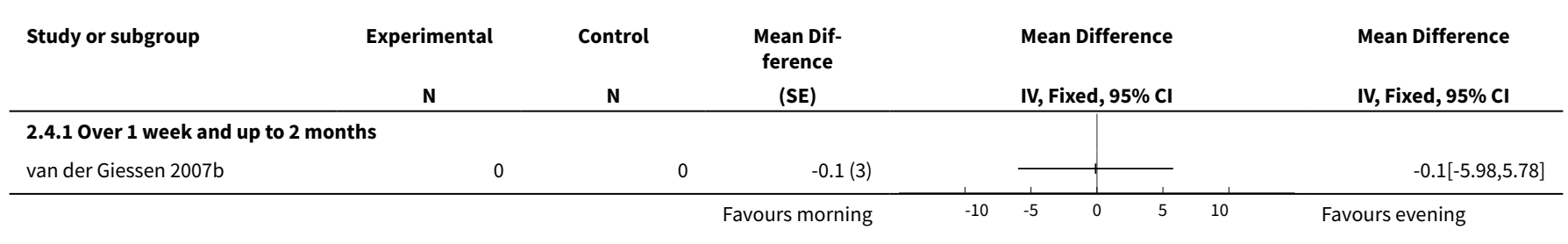

Analysis 2.5. Comparison 2 Morning versus Evening, Outcome $5 \mathrm{FEF}_{25}$ (\% pred).

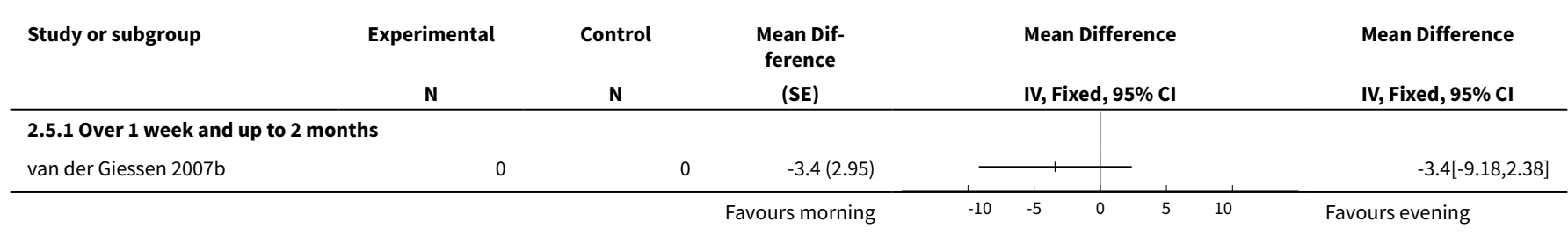

\section{ADDITIONAL TABLES}

Table 1. Symptom Scores from van der Giessen 2007a

\begin{tabular}{llll}
\hline & DNase before ACT & DNase after ACT & $\begin{array}{l}\text { P value (paired } \\
\text { t-test) }\end{array}$ \\
\hline VAS viscosity $^{*}$ & $1.3(0.2$ to 8.4$)$ & $1.3(0.2$ to 8.4$)$ & 0.73 \\
\hline VAS sputum amount $^{*}$ & $0.7(0$ to 5.1$)$ & $1.1(0.1$ to 6.6$)$ & 0.14 \\
\hline VAS daytime cough $^{*}$ & $1.7(0$ to 5.3$)$ & $1.9(1$ to 7.4$)$ & 0.51 \\
\hline VAS nightime cough $^{*}$ & $0.1(0$ to 3.4$)$ & $0.2(0$ to 5.7$)$ & 0.14 \\
\hline CSS daytime & $1.4(0$ to 3$)$ & $1.6(0$ to 3.1$)$ & 0.28 \\
\hline CSS nighttime & $0.4(0$ to 2$)$ & $0.7(0$ to 2.6$)$ & 0.06 \\
\hline
\end{tabular}

Data are mean (or median if asterisked) and range

ACT: airway clearance technique 
CSS: cough symptom score VAS: visual analogue scale

Table 2. Symptom scores from van der Giessen 2007b

\begin{tabular}{|c|c|c|c|}
\hline & $\begin{array}{l}\text { Evening } \\
\text { Mean (SD) }\end{array}$ & $\begin{array}{l}\text { Morning } \\
\text { Mean (SD) }\end{array}$ & $P$ value \\
\hline VAS viscosity & $2.1(1.6)$ & $2.5(1.6)$ & 0.22 \\
\hline VAS sputum amount & $1.9(1.8)$ & $2.1(1.6)$ & 0.26 \\
\hline VAS daytime coughing & $2.2(1.6)$ & $2.5(1.7)$ & 0.27 \\
\hline VAS nighttime coughing & $1(1)$ & $1.3(1.4)$ & 0.08 \\
\hline VAS appetite & $3(2.7)$ & $3.3(2.6)$ & 0.35 \\
\hline VAS sleep quality & $1.1(1)$ & $1.5(1.3)$ & 0.08 \\
\hline CSS daytime & $1.3(0.9)$ & $1.6(0.9)$ & 0.07 \\
\hline CSS nighttime & $0.8(0.8)$ & $1(0.9)$ & 0.27 \\
\hline
\end{tabular}

CSS: cough symptom score

SD: standard deviation

VAS: visual analogue scale

\section{AP PEN DICES}

\section{Appendix 1. PEDro search strategy 'deoxyribonuclease'}

Date of last search for all years available: 20 May 2009. Using the option 'Advanced search', the following search terms were entered into the following fields:

\begin{tabular}{ll}
\hline Field & Search term \\
\hline Abstract \& title & deoxyribonuclease \\
\hline Problem & difficulty with sputum clearance \\
\hline Subdiscipline & cardiothoracics \\
\hline
\end{tabular}

\section{Appendix 2. PEDro search strategy 'DNase'}

Date of last search for all years available: 20 May 2009. Using the option 'Advanced search', the following search terms were entered into the following fields:

\section{Field}

\section{Search term}


(Continued)
Abstract \& title
DNase

Problem

difficulty with sputum clearance

Subdiscipline

cardiothoracics

\section{Appendix 3. PEDro search strategy 'Dornase'}

Date of last search for all years available: 20 May 2009. Using the option 'Advanced search', the following search terms were entered into the following fields:

\begin{tabular}{ll}
\hline Field & Search term \\
\hline Abstract \& title & Dornase \\
\hline Problem & difficulty with sputum clearance \\
\hline Subdiscipline & cardiothoracics \\
\hline
\end{tabular}

\section{Appendix 4. PEDro search strategy 'Pulmozyme'}

Date of last search for all years available: 20 May 2009. Using the option 'Advanced search', the following search terms were entered into the following fields:

\begin{tabular}{ll}
\hline Field & Search term \\
\hline Abstract \& title & Pulmozyme \\
\hline Problem & difficulty with sputum clearance \\
\hline Subdiscipline & cardiothoracics \\
\hline
\end{tabular}

\section{Appendix 5. Clincial Trial Registries}

Date of last search for all years available: 17 July 2018.

\begin{tabular}{ll}
\hline Registry & Search terms \\
\hline ClinicalTrials.gov (www.ClinicalTrials.gov) & $\begin{array}{l}\text { deoxyribonuclease, DNase, dornase, pul- } \\
\text { mozyme }\end{array}$ \\
\hline $\begin{array}{l}\text { World Health Organization (WHO) International Clinical Trials Registry Platform (IC- } \\
\text { TRP) Search Portal (apps.who.int/trialsearch/) }\end{array}$ & $\begin{array}{l}\text { deoxyribonuclease, DNase, dornase, pul- } \\
\text { mozyme }\end{array}$ \\
\hline
\end{tabular}


WHAT'S NEW

\begin{tabular}{lll}
\hline Date & Event & Description \\
\hline 25 March 2019 & Amended & Conflict of interest declaration section updated. \\
\hline
\end{tabular}

\section{H IST ORY}

Protocol first published: Issue 3, 2009

Review first published: Issue 5, 2011

\begin{tabular}{|c|c|c|}
\hline Date & Event & Description \\
\hline 7 November 2018 & New search has been performed & $\begin{array}{l}\text { No new studies have been included in the review during this up- } \\
\text { date. Minor changes have been made throughout several sec- } \\
\text { tions of the review. }\end{array}$ \\
\hline 7 November 2018 & $\begin{array}{l}\text { New citation required but conclusions } \\
\text { have not changed }\end{array}$ & $\begin{array}{l}\text { Summary of findings tables have been added to the review, but } \\
\text { given no new trials have been included, the conclusions remain } \\
\text { unchanged. }\end{array}$ \\
\hline 19 July 2016 & New search has been performed & $\begin{array}{l}\text { A search of the Cochrane Cystic Fibrosis and Genetic Disorders } \\
\text { Group's Cystic Fibrosis Register identified two references that } \\
\text { were added to the 'Excluded studies' section of the review. One } \\
\text { was not a randomised controlled trial and one did not have tim- } \\
\text { ing of DNase as the randomised factor (Sanders 2015; Sawicki } \\
\text { 2015). }\end{array}$ \\
\hline 19 July 2016 & $\begin{array}{l}\text { New citation required but conclusions } \\
\text { have not changed }\end{array}$ & $\begin{array}{l}\text { Two new citations were excluded thus the review conclusions } \\
\text { were not altered (Sanders 2015; Sawicki 2015). }\end{array}$ \\
\hline 2 May 2013 & New search has been performed & $\begin{array}{l}\text { The searches identified: a full paper publication to an already } \\
\text { included study (Bishop 2011); four additional references to an } \\
\text { already excluded study (Bakker 2011); and one new excluded } \\
\text { study (Lahiri 2012). A further six trials (15 trials reports) identified } \\
\text { were disregarded from inclusion on title alone. }\end{array}$ \\
\hline 2 May 2013 & $\begin{array}{l}\text { New citation required but conclusions } \\
\text { have not changed }\end{array}$ & $\begin{array}{l}\text { Minor changes have been made throughout this updated version } \\
\text { of the review. }\end{array}$ \\
\hline
\end{tabular}

\section{CONTRIBUTIONS OF AUTHORS}

$\mathrm{RD}$ and ME outlined the protocol and each performed the search for trials, appraisal and data extraction.

$\mathrm{RD}$ or ME contacted the authors of trials where data are absent or difficult to interpret in the presented form.

$\mathrm{RD}$ and ME performed the data analysis.

$\mathrm{RD}$ acts as guarantor of the review.

\section{DECLARATIONS OF INTEREST}

Both authors: none known. 


\section{SOURCESOF SUPPORT}

\section{Internal sources}

- No sources of support supplied

\section{External sources}

- National Institute for Health Research, UK.

This systematic review was supported by the National Institute for Health Research, via Cochrane Infrastructure funding to the Cochrane Cystic Fibrosis and Genetic Disorders Group.

\section{DIFFERENCES BETWEEN PROTOCOLANDREVIEW}

Summary of findings tables were added as part of the 2018 update.

\section{INDEX TERMS}

\section{Medical Subject Headings (MeSH)}

Administration, Inhalation; Combined Modality Therapy [methods]; Cystic Fibrosis [^therapy]; Deoxyribonuclease I [ ${ }^{\star}$ administration \& dosage]; Drug Administration Schedule; Quality of Life; Randomized Controlled Trials as Topic; Recombinant Proteins [administration \& dosage]; Respiratory Therapy [ ${ }^{\star}$ methods]; Time Factors

\section{MeSH check words}

Adolescent; Child; Humans; Young Adult 